\title{
Immunogenic and neutralization efficacy of recombinant perfringolysin 0 of Clostridium perfringens and its C-terminal receptor-binding domain in a murine model
}

\author{
Ankita Singh $^{1} \cdot$ Prashant Rawat $^{1} \cdot$ Devapriya Choudhury $^{1}$ (i) $\cdot$ Aparna Dixit ${ }^{1}$ (I)
}

Received: 10 June 2021 / Accepted: 27 November 2021 / Published online: 15 January 2022

(c) The Author(s), under exclusive licence to Springer Science+Business Media, LLC, part of Springer Nature 2022

\begin{abstract}
Clostridium perfringens is a Gram-positive anaerobe ubiquitously present in different environments, including the gut of humans and animals. $C$. perfringens have been classified in the seven toxinotypes based on the secreted toxins that cause different diseases in humans and animals. Perfringolysin O (PFO), a cholesterol-dependent pore-forming cytolysin, is one of the potent toxins secreted by almost all $C$. perfringens isolates. The PFO acts in synergy with $\alpha$-toxin in the progression of gas gangrene in humans and necrohemorrhagic enteritis in the calves.

C. perfringens infections spread very fast, and the animals die within a few hours of the onset of infection. This necessitates the use of vaccines to control clostridial infections. Though the vaccine potential of other toxins has been reported, PFO has remained unexplored. The present study describes the immunogenic and protective potential of native recombinant PFO (WTrPFO). Since the PFO is toxic to the host cells, the non-toxic C-terminal domain of PFO (rPFOC-ter) was also assessed for its immunogenicity and protective efficacy. Immunization of mice with the purified soluble recombinant histidine-tagged WTrPFO and rPFOC-ter, expressed in E. coli, generated robust mixed immune response and T cell memory. Pre-incubation of the WTrPFO with anti-WTrPFO and rPFOC-ter antisera negated its hemolytic activity in mice RBCs, as well as its cytotoxic effect in mice peritoneal macrophages in vitro. Thus, immunization with the WTrPFO and its non-toxic C-terminal domain generated neutralizing antibodies, suggesting their vaccine potential against the PFO. Thus, the non-toxic C-terminal domain of PFO could serve as an alternative to PFO as a vaccine candidate.
\end{abstract}

Keywords Perfringolysin $\mathrm{O} \cdot$ Clostridium perfringens $\cdot$ Immune response $\cdot$ Neutralizing antibodies

\section{Introduction}

Clostridium perfringens is a fast-growing, spore-forming, Gram-positive, rod-shaped anaerobe of the Bacillaceae family $[1,2]$. It is widely present in different habitats such as soil, food, sewage, and aquatic ecosystems (marine, estuarine, and freshwater) and colonizes the gastrointestinal tract of animals and humans [3, 4]. Its ubiquitous presence in the environment is responsible for causing many histotoxic and enteric diseases in humans and animals [5]. This bacterium

Devapriya Choudhury

devapriyachoudhury@gmail.com; devach@mail.jnu.ac.in

$\triangle$ Aparna Dixit

adixit7@gmail.com; adix2100@mail.jnu.ac.in

1 Gene Regulation Laboratory, School of Biotechnology, Jawaharlal Nehru University, New Delhi 110067, India secretes more than 20 extracellular enzymes and toxins that are believed to be potent lethal factors behind pathogenicity [6]. Massive secretion of these toxins results in an outbreak of a broad range of diseases in animals and humans, such as gas gangrene, necrotic enteritis, food poisoning, and numerous enterotoxaemia [7, 8]. Further, it is believed to be responsible for local and systemic tissue damage and the rapid death of bovines [6,9].

C. perfringens strains are classified into seven toxinotypes (types A, B, C, D E, F, and G) based on the production of different toxins, namely $\alpha, \beta, \varepsilon, i$, CPE, and NetB [10]. Perfringolysin $\mathrm{O}(\mathrm{PFO})$ is secreted by all the strains, and it is believed to assist other toxins of $C$. perfringens in the onset and progression of various Clostridia-associated diseases [11]. PFO acts in synergy with $\alpha$-toxin that causes gas gangrene and bovine necrohemorrhagic enteritis [12-14]. It has also been reported to augment the virulence effect of $\varepsilon$-toxin in causing type $\mathrm{D}$ enterotoxemia in a mouse model 
[12-14]. Despite the role that the PFO plays in clostridial diseases, it has not been explored for its immunogenic and vaccine potential. It has rightly been referred to as "the underrated Clostridium perfringens toxin" due to lack of attention from the research community [15]. After exposure to $C$. perfringens without any apparent premonitory clinical signs of necrohemorrhagic enteritis, the quick death of animals demands a safe and efficient preventive measure such as vaccination to control clostridial infections $[1,16]$. In the past decades, efficient genetically engineered and denatured toxoid-based vaccines have been commercially developed that could confer protective immunity to economically important livestock, including sheep, goats, and bovines, against $C$. perfringens-associated infections [17, 18]. However, the protective effect of formaldehyde denatured toxoidbased antibodies generated in calves was diminished in the intestinal loop model for bovine necrohemorrhagic enteritis compared to antibodies against native toxins [19]. Since active toxins cannot be considered safe for vaccine development, alternative non-toxic variants of the native toxins need to be assessed for the development of safe and efficient vaccines. Genetically modified toxoids with reduced toxic activity or immunologically active fragments of the essential toxins in this regard could be a good choice. Though recombinant $\varepsilon, \beta$, and $\alpha$ toxins have been assessed for their vaccine potential [20-24], their use is restricted against the specific toxinotypes of $C$. perfringens. The PFO, secreted by all toxinotypes of $C$. perfringens, has been reported as the second most immunogenic toxin of $C$. perfringens type A after the $\alpha$-toxin and thus highlights the importance of PFO as a potential candidate for vaccine development against $C$. perfringens [19].

The crystal structure of the PFO monomer revealed that it could be divided into four domains, domain 1 (D1), domain 2 (D2), domain 3 (D3), and domain 4 (D4) or C-terminal domain predominantly made up of $\beta$-strands. Domain 1 encompasses amino acid residues 37-53, 90-178, 229-274, and 350-373; domain 2 encompasses amino acid residues 54-89 and 374-390, and domain 3 encompasses amino acid residues 179-228 and 275-349; thus, these are not in a continuous way. However, in the C-terminal domain or domain 4 , the residues are continuous (391-500) [25]. The C-terminal domain (domain 4) is the smallest functional unit of PFO, responsible for the cholesterol recognition and binding of the toxin to cholesterol-containing membranes $[26,27]$. The isolated C-terminal domain was reported to be non-toxic and could recognize and bind with membrane cholesterol [28].

The current study was therefore undertaken to produce soluble recombinant PFO using heterologous expression system and evaluate its immunogenicity in the mice model. Furthermore, since the whole toxin has been reported to be toxic to the host cell, we also assessed the immunogenicity of its receptor-binding domain, i.e., C-terminal domain produced using recombinant routes in parallel with WTrPFO. Further, the antisera generated against the full-length mature PFO and the C-terminal domain was assessed for its neutralizing potential in vitro.

\section{Materials and methods}

\section{Chemicals and reagents}

All chemicals used in the study were of molecular biology grade. The chemicals and the bacterial growth medium used in the study are acquired from Sisco Research Laboratories Pvt. Ltd. (SRL), India, and Sigma-Aldrich Chemical Co., USA. PageRuler Protein molecular weight markers were from New England Biolab, USA. $\mathrm{Ni}^{2+}$-NTA agarose and the bicinchoninic acid (BCA) protein estimation kit were purchased from G-Biosciences, USA. Monoclonal anti-polyhistidine, anti-mouse-IgG ( $\mathrm{Fc}$ specific)-alkaline phosphataseconjugated antibody produced in goat was procured from Sigma-Aldrich Chemical Co., USA. Cell proliferation kit (XTT based) and Pierce ${ }^{\circledR}$ LDH cytotoxicity assay kit were purchased from Biological Industries and Thermo Fisher Scientific, USA, respectively.

\section{Bacterial strains and animals}

E. coli strains DH5 $\alpha$ and BL21( $\lambda$ DE3)pLysS cells used to propagate the plasmid DNA and recombinant protein expression, respectively, were procured from Novagen, USA.

The Institutional Animal Ethics Committee of the University approved the use of animals for the immunization study (project code IAEC \# 03/2019). All procedures were performed as per the guidelines and recommendations of the committee. The Inbred Swiss albino mice (female, aged 4-6 weeks old, $18 \pm 2 \mathrm{~g}$ ) were obtained from the Central Laboratory Animal Resources (CLAR), Jawaharlal Nehru University, New Delhi. The mice were housed ( $n=5$ mice/ group/cage) in fixed light and dark conditions and were kept on drinking water (RO) and food ad libitum.

\section{Expression constructs}

Synthetic gene constructs harboring the mature full-length pfo of $C$. perfringens (without the signal sequence) and its deletion variant harboring only the $\mathrm{C}$-terminal domain comprising 390 to $499\left(\mathrm{PFO}_{\mathrm{C}-\text { ter }}\right)$ residues were designed based on the sequence information available for $C$. perfringens pfo gene (GenBank Accession number: M36704). The respective synthetic genes cloned into expression vector pET22b(+) at the NdeI and XhoI restriction sites were procured from GenScript, USA, and designated $\mathrm{pET} 22 . \mathrm{PFO}_{\mathrm{wt}}$ 
and pET22.PFO $\mathrm{C}_{\mathrm{C} \text {-ter }}$, respectively. The recombinant proteins $\mathrm{WTrPFO}$ and $\mathrm{rPFO}_{\mathrm{C}-\text { ter }}$ encoded from the two constructs would be 482 aa $(\sim 54 \mathrm{kDa})$ and 119 aa $(\sim 14 \mathrm{kDa})$ residues long (including the amino acids contributed from the vector), respectively.

\section{Recombinant expression and subcellular localization analysis of WTrPFO and rPFOC-ter}

Expression analysis of the recombinant proteins (WTrPFO and $\left.\mathrm{rPFO}_{\mathrm{C}-\mathrm{ter}}\right)$ was carried out essentially as described earlier [29]. Briefly, secondary cultures (prepared with $1 \%$ of overnight culture) of the E. coli BL21 ( $\lambda \mathrm{DE} 3)$ pLysS harboring the plasmids pET22.PFO $O_{\mathrm{wt}}$ and pET22.PFO $O_{\mathrm{C}-\mathrm{ter}}$ for recombinant expression, respectively, were induced with 0.8 $\mathrm{mM}$ IPTG for $8 \mathrm{~h}$. An aliquot (1 ml) of the uninduced culture was taken out prior to induction. The cells were harvested (6000 rpm, $4{ }^{\circ} \mathrm{C}, 10 \mathrm{~min}$; Eppendorf centrifuge 5415R, UK), and the cell lysates were analyzed on $12 \%$ SDS-PAGE.

Localization of expression analysis was carried out as described earlier [30]. Briefly, the induced cell lysates of the E. coli BL21( $\lambda \mathrm{DE} 3)$ pLysS cells expressing WTrPFO and rPFOC-ter were centrifuged at $13000 \mathrm{rpm}$ (Eppendorf centrifuge 5415R, UK) for $30 \mathrm{~min}$ at $4{ }^{\circ} \mathrm{C}$ to prepare the soluble (supernatant) and insoluble (pellet) fractions. The pellet was treated with $8 \mathrm{M}$ urea buffer $(20 \mathrm{mM}$ Tris- $\mathrm{HCl}, \mathrm{pH} 8.0,500$ $\mathrm{mM} \mathrm{NaCl}$, and $8 \mathrm{M}$ urea) to solubilize the proteins. The fractions were analyzed by SDS-PAGE (12\%), followed by Coomassie Brilliant Blue (CBB-R250) staining.

Optimization of induction time for maximum expression was performed by inducing the cultures with $0.8 \mathrm{mM}$ for the different time points. The inducer concentration was optimized by inducing the cultures with different concentrations of IPTG for $8 \mathrm{~h}$. The soluble and insoluble fractions of the cell lysates of induced cultures (1 mM IPTG) at different temperatures $\left(16^{\circ} \mathrm{C}, 25^{\circ} \mathrm{C}\right.$, and $\left.37^{\circ} \mathrm{C}\right)$ were analyzed by SDS-PAGE.

\section{Purification of WTrPFO and rPFOC-ter}

Large-scale purification of the two recombinant proteins (WTrPFO and $\mathrm{rPFO}_{\mathrm{C}-\mathrm{ter}}$ ) from the soluble fraction was done using $\mathrm{Ni}^{2+}$-NTA affinity chromatography essentially as described earlier [30]. The soluble fraction of the cell lysates was prepared from the induced cell cultures (1 mM IPTG at $16{ }^{\circ} \mathrm{C}$ for $22 \mathrm{~h}$ ). The soluble fraction was incubated with the $\mathrm{Ni}^{2+}$-NTA agarose resin. After removing the non-specifically bound proteins by thoroughly washing with wash buffer (20 mM imidazole, $20-\mathrm{mM}$ potassium phosphate buffer $\mathrm{pH} 8.0,500 \mathrm{mM} \mathrm{NaCl}, 1 \mathrm{mM}$ PMSF), specifically bound recombinant proteins were eluted using $5 \mathrm{ml}$ aliquots of wash buffer containing different imidazole concentrations. The eluted fractions along with flow-through were analyzed on $12 \%$ SDS-PAGE. The fractions showing pure proteins were pooled and dialyzed against $20-\mathrm{mM}$ potassium phosphate buffer $(\mathrm{pH} 8)$ and stored in small aliquots at $-80{ }^{\circ} \mathrm{C}$ for further use.

\section{Western blot analysis}

Western blotting was carried out as described earlier [31]. The cell lysates prepared from the uninduced and induced cultures or purified proteins were resolved by $12 \%$ SDSPAGE. The proteins were transferred to the nitrocellulose membrane at constant voltage $\left(50 \mathrm{~V}\right.$ for $2 \mathrm{~h}$ at $\left.4{ }^{\circ} \mathrm{C}\right)$ using $1 \times$ transfer buffer [25 mM Tris-HCl, pH 8.3; $192 \mathrm{mM}$ glycine; and $20 \%(\mathrm{v} / \mathrm{v})$ methanol]. The membrane was then incubated in blocking buffer [2\% BSA in $1 \times$ PBST solution $(137 \mathrm{mM}$ $\mathrm{NaCl}, 2.7 \mathrm{mM} \mathrm{KCl}, 10 \mathrm{mM} \mathrm{Na} \mathrm{HPO}_{4}, 1.8 \mathrm{mM} \mathrm{KH}_{2} \mathrm{PO}_{4}$, $\mathrm{pH} 7.4$, and $0.05 \%$ Tween 20 ) overnight at $4{ }^{\circ} \mathrm{C}$ followed by three $1 \times$ PBST washes of 10 min each. The membrane was then incubated with the primary antibody (1:10,000 in PBS) for $1 \mathrm{~h}$ at RT. After thoroughly washing with $1 \times$ PBST, the membrane was incubated with secondary antibody [1:10000; alkaline phosphatase (AP)-conjugated goat anti-mouse/rabbit antibody] at RT for $1 \mathrm{~h}$, followed by $1 \times$ PBST washes as before. 5-Bromo-4-chloro-3-indolyl phosphate (BCIP)/ nitroblue tetrazolium (NBT)] substrate was added to develop the color. The image was captured by Gel-doc (Bio-Rad Laboratories, Inc., USA).

\section{Mice immunization}

Pre-immune sera were collected from the mice before immunization. Mice ( $n=5$ per group) were immunized with purified recombinant proteins $(30 \mu \mathrm{g})$ emulsified in complete Freund adjuvant (1:1) through the intraperitoneal route (I.P.). Mice immunized with $1 \times$ PBS-complete Freund adjuvant emulsion were included as controls. Subsequent boosters with the same protein concentrations emulsified in incomplete Freund adjuvant were given on days 14, 28, and 42 after primary immunization. Mice were bled through retroorbital plexus before immunization (day 0 ) for collection of pre-immune (PI) serum, on day 14 post-immunization, and a week after each booster administration (day 21 , day 35 , and day 49). The collected blood was kept at $25^{\circ} \mathrm{C}$ for $1 \mathrm{~h}$, followed by centrifugation at $8000 \mathrm{rpm}$ (Eppendorf centrifuge 5415R, UK), $4{ }^{\circ} \mathrm{C}$ for $10 \mathrm{~min}$ [32]. The sera were stored at $-20^{\circ} \mathrm{C}$ in small aliquots till further use.

\section{Enzyme-linked immunosorbent assay (ELISA)}

ELISA was performed for antibody titer determination and antibody isotyping of the antiserum generated in immunized mice [32]. Briefly, proteins (500 $\mathrm{ng} / 100 \mu \mathrm{l}$ in each well, in triplicates) were coated in flat-bottom 96-well ELISA plates 
overnight at $4{ }^{\circ} \mathrm{C}$. The unbound proteins were removed by washing three times with $1 \times$ PBST, followed by blocking with $2 \%$ BSA prepared in $1 \times$ PBST at $37{ }^{\circ} \mathrm{C}$ for $1 \mathrm{~h}$. After rewashing the wells with $1 \times$ PBST as before, different dilutions $(1: 10,000$ to $1: 160,000)$ of the antisera or isotypespecific antibodies $(1: 10,000)$ were added to the well and incubated at $37^{\circ} \mathrm{C}$ for $1 \mathrm{~h}$. The plates were washed with $1 \times$ PBST, as stated before. Secondary antibody (AP-conjugated anti-mouse antibody/anti-rabbit antibody $(1: 10,000,100 \mu \mathrm{l} /$ well) was added and incubated at $37{ }^{\circ} \mathrm{C}$ for $1 \mathrm{~h}$, followed by three $1 \times$ PBST washes. The color was developed by adding the substrate ( $p$-nitrophenyl phosphate substrate, $1 \mathrm{mg}$ / $\mathrm{ml}$ ) and incubating at room temperature for $20 \mathrm{~min}$. The absorbance was measured at $420 \mathrm{~nm}$. The endpoint titers were determined as the highest dilution of the sera that gave a positive absorbance over and above that obtained with preimmune serum [33].

Levels of different isotypes of $\operatorname{IgG}(\operatorname{IgG} 1, \operatorname{IgG} 2 \mathrm{a}, \mathrm{IgG} 2 \mathrm{~b})$ in the antisera were determined by indirect ELISA using isotype-specific horseradish peroxidase (HRP)-conjugated secondary antibodies from BD Biosciences, USA, as per the manufacturer's instructions.

\section{Lymphocyte proliferation assay}

For the isolation of splenocytes, immunized mice were sacrificed after 1 week of the second booster, i.e., on day 35 of primary immunization, and the spleen was surgically removed under aseptic conditions. The splenocytes were isolated as described earlier [31]. Splenocytes from the recombinant protein immunized mice and PBS-immunized mice (control) were seeded $\left(1 \times 10^{6}\right.$ cells $/ 100 \mu 1 /$ well, in triplicates) in a 96-well culture plate and stimulated with respective protein $(20 \mu \mathrm{g}$ in $100 \mu \mathrm{l}$ PBS). PBS-stimulated cells were included as a control. The stimulated cells were cultured at $37^{\circ} \mathrm{C}$ for $24 \mathrm{~h}, 48 \mathrm{~h}$, and $72 \mathrm{~h}$, under $5 \% \mathrm{CO} 2$ humidified atmosphere. The culture supernatant was collected at different time intervals, and the cell proliferation was assayed using XTT assay as per the manufacturer's direction. The absorbance was measured at $450 \mathrm{~nm}$ using an ELISA plate reader (Tecan, USA).

\section{Cytokine ELISA}

The immune response generated $\left(\mathrm{CD}^{+}{ }^{+} \mathrm{T}\right.$ helper cell proliferation) in the culture supernatants of the protein- and PBS-stimulated splenocytes was evaluated by determining IL-4 and IFN- $\gamma$ levels using cytokine specific ELISA kit (Becton-Dickinson Pharmingen, USA).

\section{Hemolytic activity assay}

Hemolytic activity of the purified WTrPFO was measured using mice blood by the method of Tweten [34]. Mice RBCs were separated from the blood as described by Hanson et al., with minor modifications [35]. Briefly, mice blood $(1 \mathrm{ml})$ was collected through the retro-orbital plexus vein in EDTA $(1.5 \mathrm{mg} / \mathrm{ml})$ to prevent coagulation and centrifuged at $500 \times \mathrm{g}$ (Eppendorf microcentrifuge $5415 \mathrm{R}$ ) at $4{ }^{\circ} \mathrm{C}$ for 5 min. The supernatant (plasma) was discarded, and the pellet was washed three times with $1 \times \mathrm{PBS}, \mathrm{pH} 7.4$ at $4{ }^{\circ} \mathrm{C}$. The washed blood cell pellet was suspended in 10 volumes of $1 \times$ PBS to pellet volume. The RBCs $\left(2.5 \times 10^{6}\right.$ in $\left.50 \mu \mathrm{l}\right)$ were treated with different concentrations of the WTrPFO $(0.4 \mu \mathrm{g} /$ $\mathrm{ml}$ to $2.0 \mu \mathrm{g} / \mathrm{ml}$ ) in a final volume of $150 \mu \mathrm{l}$ and incubated at $37^{\circ} \mathrm{C}$ for $1 \mathrm{~h}$. The samples were centrifuged at $1000 \mathrm{rpm}$ for 5 min at $4{ }^{\circ} \mathrm{C}$ to separate the cell debris. Hemoglobin present in the supernatant was measured at $540 \mathrm{~nm}$. The cells treated with PBS and 1\% SDS were included as negative and positive controls, respectively. The SDS-treated cells were considered to have undergone $100 \%$ lysis. Therefore, the percentage of hemolysis in the treated samples is determined with respect to SDS-treated cells. One hemolytic activity (HU) unit was defined as the amount of WTrPFO required to cause $50 \%$ hemolysis.

For assessing the ability of the anti-WTrPFO and anti$\mathrm{rPFO}_{\mathrm{C} \text {-ter }}$ antisera to inhibit the hemolytic activity of the WTrPFO, pooled antisera collected from all mice of each group on day 35 post-immunization were used. A range of dilutions of both antisera (50-5\%) was prepared in $1 \times$ PBS. The WTrPFO (50 $\mu \mathrm{l}, 0.2 \mathrm{mg} / \mathrm{ml})$ that caused $80 \%$ hemolysis was incubated with an equal volume of the diluted antiserum $(50 \mu \mathrm{l})$ and neat antiserum at $37^{\circ} \mathrm{C}$ for $30 \mathrm{~min}$. The proteinantisera mixture was then added to RBCs $\left(2.5 \times 10^{6} \mathrm{RBCs}\right.$ in $50 \mu \mathrm{l}$ ) and allowed to incubate at $37^{\circ} \mathrm{C}$ for $1 \mathrm{~h}$. The cells were then centrifuged at $1000 \mathrm{rpm}$ for $5 \mathrm{~min}$ (Eppendorf microcentrifuge), and the supernatant was collected carefully. The absorbance at $540 \mathrm{~nm}$ was measured to assess the inhibition of hemolysis by the antisera.

\section{Cytotoxicity of WTrPFO and PFO $_{\mathrm{C} \text {-ter }}$}

Cytotoxic activity of the recombinant proteins was evaluated using phagocytic macrophages employing LDH cytotoxicity assay kit as described earlier [29]. Mice peritoneal macrophages $\left(5 \times 10^{4}\right.$ cells $/ 100 \mu \mathrm{l} /$ well $)$ isolated by the method described by Ray and Dittel [36] were treated with different concentrations of the proteins $(10-100 \mu \mathrm{g} /$ $\mathrm{ml}$, in triplicates) and incubated at $37^{\circ} \mathrm{C}$ for $24 \mathrm{~h}$ in a $\mathrm{CO}_{2}$ $(5 \%)$ incubator. The culture supernatants of the treated cells were subjected to LDH coupled activity assay as per the manufacturer's directions. The absorbance measured 
at $490 \mathrm{~nm}$ was directly proportional to the released $\mathrm{LDH}$ and cytotoxicity of the recombinant protein(s).

The antisera against the WTrPFO and $\mathrm{rPFO}_{\mathrm{C}-\text { ter }}$ collected on day 35 post-immunization were evaluated for their neutralization capacity against the WTrPFO toxicity in mice peritoneal macrophages. The WTrPFO (100 $\mu \mathrm{g} / \mathrm{ml}, 50 \mu \mathrm{l})$ was pre-incubated with an equal volume of different dilutions of the antisera $(1: 10-1: 10,000)$ for 37 ${ }^{\circ} \mathrm{C}$ for $30 \mathrm{~min}$. Mice peritoneal macrophages were seeded in a 96 -well plate $\left(5 \times 10^{4}\right.$ macrophages $/ 100 \mu \mathrm{l} /$ well, in triplicates) and treated with the WTrPFO pre-incubated with different dilutions of antiserum at $37{ }^{\circ} \mathrm{C}$ for $24 \mathrm{~h}$ in $5 \% \mathrm{CO}_{2}$ atmosphere. The cells treated with WTrPFO alone were included as positive control and pre-incubated with the pre-immune serum as a negative control. Percentage neutralization of cytotoxicity in the samples pre-incubated with different antisera was calculated with respect to cells treated only with the WTrPFO (100\% cytotoxicity).

\section{Statistical analysis}

The data represent the mean \pm S.D. of two independent experiments performed in triplicates. Statistical significance of the difference between the experimental and control was determined using one-way ANOVA or two-tailed Student's $t$-test as applicable using Prism 8.0 (Graphpad, CA, USA).

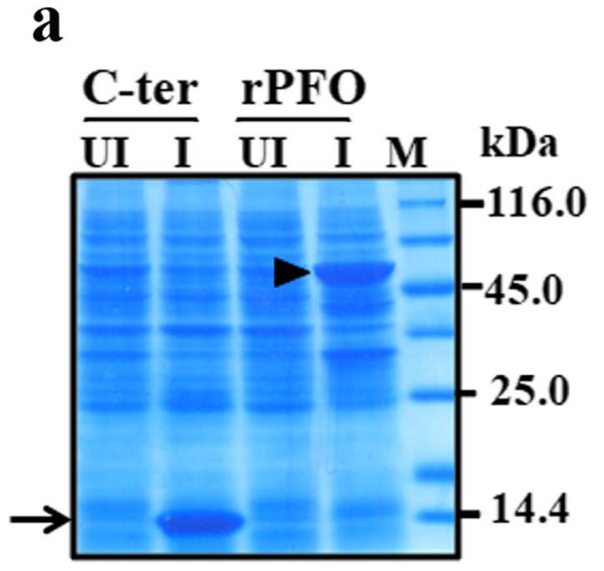

Fig. 1 a Expression analysis of WTrPFO and $\mathrm{rPFO}_{\mathrm{C}-\text { ter }}$. Uninduced and induced cell lysates $(\sim 30 \mu \mathrm{g}$ each) of both $E$. coli BL21 $(\lambda \mathrm{DE} 3)$ pLysS cells harboring pET22.PFO ${ }_{\mathrm{wt}}$ and pET22.PFO $O_{\mathrm{C}-\mathrm{ter}}$ were analyzed by SDS-PAGE (12\%). An intense band of the WTrPFO $(\sim 54 \mathrm{kDa}, \mathrm{rPFO})$ and $\mathrm{rPFO}_{\mathrm{C}-\mathrm{ter}}(\sim 14 \mathrm{kDa}, \mathrm{C}$-ter $)$, respectively, is present only in the induced cell lysates of the respective constructs. b Western blot analysis of the induced and uninduced cell lysates of

\section{Results}

\section{Expression and purification of WTrPFO and $\mathrm{rPFO}_{\mathrm{C}-\mathrm{ter}}$}

The expression of $\mathrm{WTrPFO}$ and $\mathrm{rPFO}_{\mathrm{C}-\text { ter }}$ was achieved in the induced cell lysates of $E$. coli BL21( $\lambda \mathrm{DE} 3)$ pLysS harboring the pET22.PFO ${ }_{\mathrm{wt}}$ and pET22. $P F O_{C \text {-ter }}$, respectively, upon induction with $1 \mathrm{mM}$ IPTG (Fig. 1a). A strong band of $\sim 14 \mathrm{kDa}$ and $\sim 54 \mathrm{kDa}$ was exclusively observed in the induced cell lysates (lanes I) of E. coli BL21( $\lambda \mathrm{DE} 3) \mathrm{pLysS}$ cells expressing $\mathrm{rPFO}_{C \text {-ter }}(\mathrm{C}$-ter) and WTrPFO (rPFO), respectively. No bands were detected in the uninduced cell lysates (lanes UI) of the respective cells harboring pET22. $P F O_{C \text {-ter }}$ and pET22. $F O_{\text {wt }}$. Western blot analysis, using the monoclonal anti-histidine tag antibody, confirmed the authenticity of the expressed proteins as distinct bands at the expected position of WTrPFO $(\sim 54 \mathrm{kDa})$ and $\mathrm{rPFO}_{\mathrm{C} \text {-ter }}$ $(\sim 14 \mathrm{kDa})$ were observed only in the respective induced cell lysates (Fig. 1b, lanes I). Inducer concentration optimization showed the expression of WTrPFO and $\mathrm{rPFO}_{\mathrm{C} \text {-ter }}$ to occur at a concentration as low as $0.1 \mathrm{mM}$ (Supplementary Fig. 1a and b, respectively). The expression of WTrPFO increased slightly with the increase in IPTG concentration, with maximum expression at $0.8 \mathrm{mM}$. Unlike the WTrPFO, the $\mathrm{rPFO}_{\mathrm{C} \text {-ter }}$ expression did not significantly increase with increasing inducer concentration. Time kinetics of WTrPFO expression showed an increase in expression with induction time till $8 \mathrm{~h}$, beyond which there is no further increase in expression with the increase in induction time (Supplementary Fig. 2a). The $\mathrm{rPFO}_{\mathrm{C}-\text { ter }}$ expression was found to increase

b

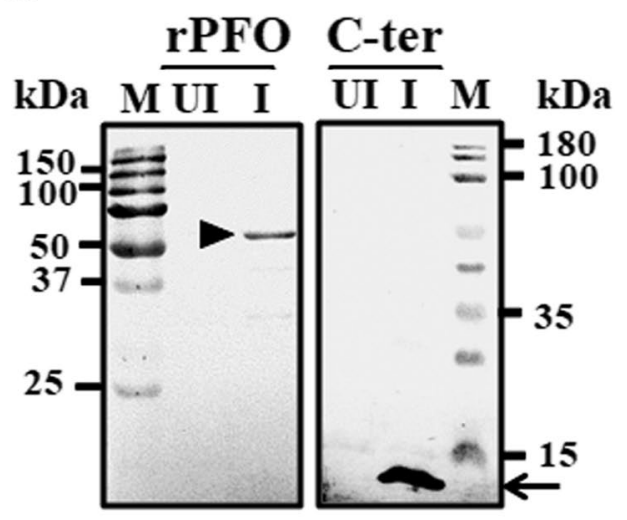

E. coli $\mathrm{BL} 21(\lambda \mathrm{DE} 3) \mathrm{pLysS}$ cells expressing WTrPFO and $\mathrm{rPFO}_{\mathrm{C}-\mathrm{ter}}$ using anti-His monoclonal antibody. Lanes "UI" and "I" represent uninduced and induced cell lysates of $E$. coli BL21( $\lambda \mathrm{DE} 3)$ pLysS cells harboring pET22.PFO $\mathrm{wt}_{\mathrm{t}}(\mathrm{rPFO})$ and $\mathrm{pET} 22 . P F O_{\mathrm{C}-\mathrm{ter}}(\mathrm{C}$-ter) in both the panels. Lane $\mathrm{M}$ denotes the protein molecular weight marker $(\mathrm{kDa})$. Arrowhead and arrow in both the panels point to the WTrPFO at $\sim 54 \mathrm{kDa}$ and rPFOC-ter at $\sim 14 \mathrm{kDa}$, respectively 
with induction time, with maximum expression observed in overnight induced culture (Supplementary Fig. 2b). The expression analysis of both the proteins (WTrPFO and $\left.\mathrm{rPFO}_{\mathrm{C}-\text { ter }}\right)$ at different temperatures $\left(16^{\circ} \mathrm{C}, 25^{\circ} \mathrm{C}\right.$, and 37 ${ }^{\circ} \mathrm{C}$ ) for $8 \mathrm{~h}$ showed the presence of a dominant band at the expected positions (Fig. 2a and b). Both the proteins showed maximum expression at $37^{\circ} \mathrm{C}$. At $16{ }^{\circ} \mathrm{C}$, the expression of both the proteins was slightly lower. Therefore, the induction at $16{ }^{\circ} \mathrm{C}$ was performed for $22 \mathrm{~h}$ (overnight) to obtain higher amounts of the protein for further analysis.

Analysis of the soluble (lane S) and insoluble (lane P) fractions of the induced cell lysates cultured at $25^{\circ} \mathrm{C}$ and $37{ }^{\circ} \mathrm{C}$ for $8 \mathrm{~h}$ showed WTrPFO (Fig. 3a) and $\mathrm{rPFO}_{\mathrm{C} \text {-ter }}$ (Fig. 3b) to be exclusively present in the insoluble fraction (lane $\mathrm{P}$ ). However, when the expression of the $\mathrm{WTrPFO}$ and $\mathrm{rPFO}_{\mathrm{C}-\text { ter }}$ was induced at $16^{\circ} \mathrm{C}$ for $22 \mathrm{~h}$, the

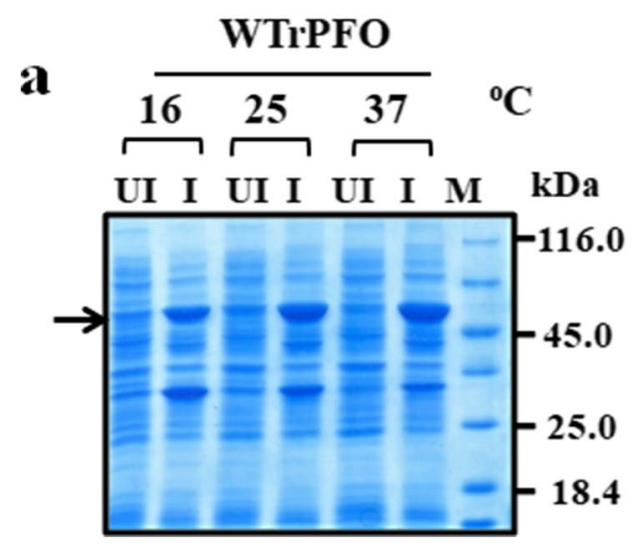

Fig. 2 Optimization of temperature for WTrPFO and $\mathrm{rPFO}_{\mathrm{C}-\mathrm{ter}}$ expression. The E. coli BL21( $\lambda \mathrm{DE} 3)$ pLysS cells harboring pET22.PFO $O_{\mathrm{wt}}(\mathbf{a})$ and $\mathrm{pET} 22 . P F O_{\mathrm{C}-\text { ter }}(\mathbf{b})$ were induced with $1 \mathrm{mM}$ IPTG for $8 \mathrm{~h}$ at different temperatures. The cell lysates were analyzed recombinant proteins were predominantly present in the soluble fractions (lane $\mathrm{S}$ in both the panels). Therefore, for large-scale purification, the cultures were induced at 16 ${ }^{\circ} \mathrm{C}$ for $22 \mathrm{~h}$, and the $\mathrm{WTrPFO}$ and $\mathrm{rPFO}_{\mathrm{C} \text {-ter }}$ were purified from the soluble fraction using $\mathrm{Ni}^{+2}$-NTA agarose chromatography. The specifically bound proteins were eluted with 100-mM imidazole (Fig. 4). Both the WTrPFO and $\mathrm{rPFO}_{\mathrm{C} \text {-ter }}$ could be purified near homogeneity ( $>99 \%$ ), as evident from a single band of the purified WTrPFO (Fig. 4a, lane 1) and $\mathrm{rPFO}_{\mathrm{C}-\text { ter }}$ (Fig. 4b, lane 1) at their expected positions ( $\sim 54 \mathrm{kDa}$ and $\sim 14 \mathrm{kDa}$, respectively) which was detected on SDS-PAGE. The yield of the purified $\mathrm{WTrPFO}$ and $\mathrm{rPFO}_{\mathrm{C} \text {-ter }}$ was determined to be $70 \mathrm{mg}$ and $75 \mathrm{mg}$, respectively, from the $1 \mathrm{~L}$ culture at shake flask level.

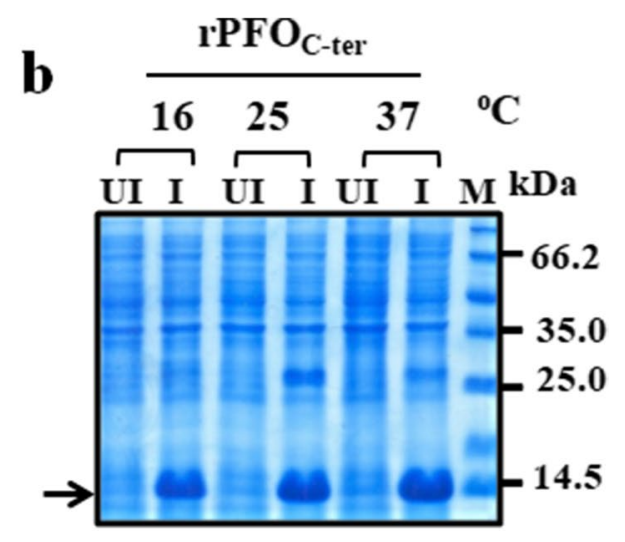

by $12 \%$ SDS-PAGE. Lanes "UI" and "I" depict the uninduced and induced cell lysates of the respective cells. "M" indicates the protein molecular weight marker $(\mathrm{kDa})$. Arrow in panel a and panel b points to the WTrPFO $(\sim 54 \mathrm{kDa})$ and $\mathrm{rPFO}_{\mathrm{C}-\mathrm{ter}}(\sim 14 \mathrm{kDa})$, respectively
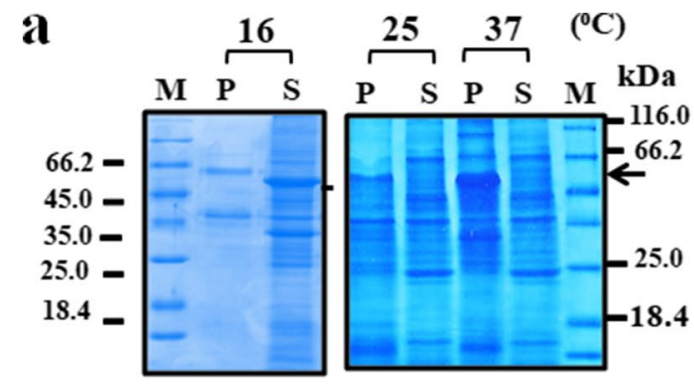
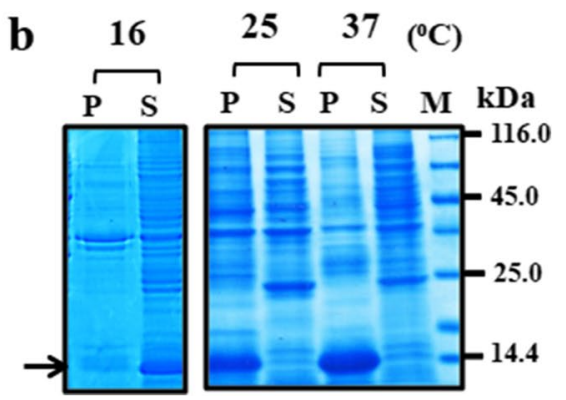

Fig. 3 Localization of $\mathrm{WTrPFO}$ and $\mathrm{rPFO}_{\mathrm{C}-\mathrm{ter}}$ expression. Soluble and insoluble fractions of the induced $E$. coli BL21( $\lambda \mathrm{DE} 3)$ pLysS cells harboring pET22.PFO $\mathrm{wt}_{\mathrm{w}}(\mathbf{a})$ and pET22.PFO $\mathrm{C}_{\mathrm{C}-\mathrm{ter}}(\mathbf{b})$ induced at different temperatures were analyzed by SDS-PAGE (12\%). Lanes P and $\mathrm{S}$, in both the panels, depict the insoluble pellet and the soluble fractions of the respective induced cell lysates. Temp $\left({ }^{\circ} \mathrm{C}\right)$ indicates culture temperature. The arrows in panel $\mathbf{a}$ and panel $\mathbf{b}$ indicate the WTrPFO $(\sim 54 \mathrm{kDa})$ and $\mathrm{rPFO}_{\mathrm{C}-\mathrm{ter}}(\sim 14 \mathrm{kDa})$ expressed either in the soluble or insoluble fractions, respectively. $\mathrm{M}$ denotes the protein molecular weight marker $(\mathrm{kDa})$ 
$\mathbf{a} \quad \mathbf{b}$
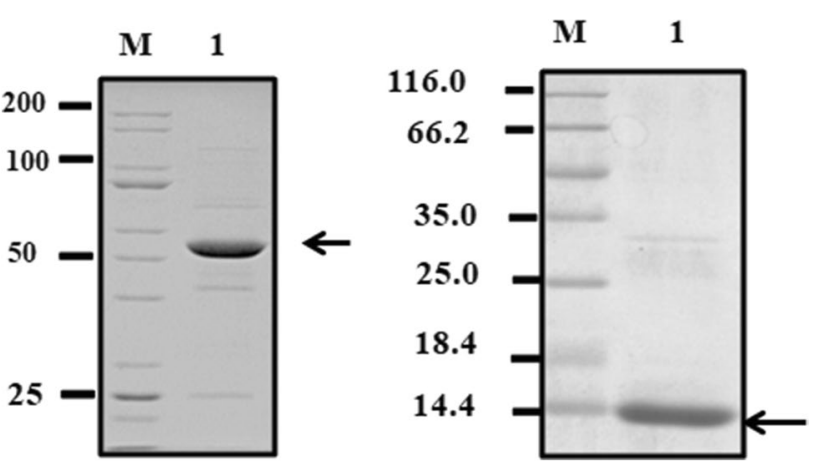

Fig. 4 Purification of recombinant WTrPFO and $\mathrm{PPFO}_{\mathrm{C}-\mathrm{ter}}$. The soluble fractions of the cell lysates of $E$. coli BL21( $\lambda$ DE3)pLysS cells harboring pET22.PFO $\mathrm{wt}_{\mathrm{w}}(\mathbf{a})$ and $\mathrm{pET} 22 . P F O_{\mathrm{C}-\mathrm{ter}}(\mathbf{b})$ cultures, induced with 1-mM IPTG at $16{ }^{\circ} \mathrm{C}$ for $22 \mathrm{~h}$, were subjected to $\mathrm{Ni}^{+2}-\mathrm{NTA}$ chromatography. The purified proteins $(\mathrm{P})$ were analyzed by SDSPAGE (12\%). M indicates the protein molecular weight markers $(\mathrm{kDa})$. The arrow points to the purified recombinant proteins

\section{Biological activity of WTrPFO}

In order to see if the histidine-tagged WTrPFO retained its biological activity, it was evaluated for its hemolytic and cytotoxic activities using mice RBCs and mice peritoneal macrophages, respectively. As shown in Fig. 5a, hemolysis $(\sim 20 \%)$ could be seen at a concentration of $0.8 \mu \mathrm{g} / \mathrm{ml}$ of WTrPFO with respect to $1 \%$ SDS (included as a positive control and considered to cause $100 \%$ lysis). A dosedependent increase in the hemolysis was observed, and at the $2 \mu \mathrm{g} / \mathrm{ml}$ of WTrPFO, $\sim 80 \%$ lysis was observed. Hemolytic activity of purified WTrPFO from the soluble fraction was determined as $10^{5} \mathrm{HU} / \mathrm{mg}$ of protein.

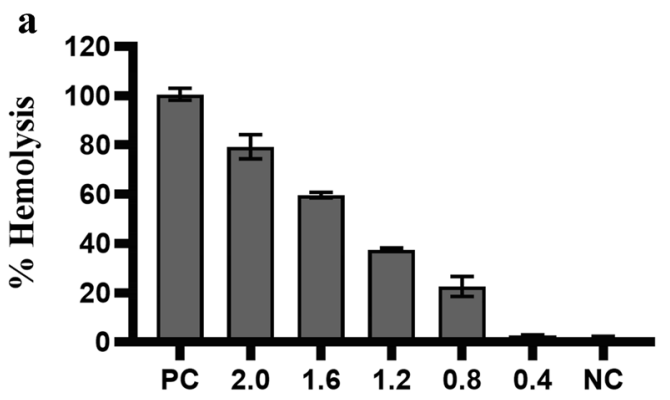

Conc. $(\mu \mathrm{g} / \mathrm{ml})$

Fig. 5 Determination of biological activities of WTrPFO. a Hemolytic activity analysis. Mice RBCs $\left(2.5 \times 10^{6}\right.$ in $\left.50 \mu \mathrm{l}\right)$ were treated with different concentrations of WTrPFO $(0.4-2.0 \mu \mathrm{g} / \mathrm{ml})$ in a final reaction volume of $150 \mu \mathrm{l}$. Percentage hemolysis was determined with respect to $1 \%$ SDS included as positive control and considered as $100 \%$ hemolysis. b Cytotoxic activity of WTrPFO. Mice peritoneal macrophages $\left(5 \times 10^{4}\right.$ cells $/ 100 \mu \mathrm{l} /$ well $)$ were treated with dif-
The purified WTrPFO was biologically active, as evident from its cytotoxicity towards mice peritoneal macrophages evaluated by the LDH release assay (Fig. 5b). Like the hemolytic activity, an increase in percentage cytotoxicity was observed with an increase in WTrPFO concentration, and $\sim 84 \%$ cytotoxicity was observed at $100 \mu \mathrm{g} / \mathrm{ml}$ concentration with respect to $10 \times$ lysis buffer, included as positive control and considered to cause $100 \%$ cell death.

\section{Immune response analysis (antibody titer and isotype determination)}

Since the study was targeted to carry out a comparative analysis of the immunogenic and neutralizing potential of the $\mathrm{WTrPFO}$ and $\mathrm{rPFO}_{\mathrm{C} \text {-ter }}$, immunization studies were performed with the two proteins. The immunoglobulin ( $\operatorname{IgG})$ levels in antisera of both WTrPFO (Fig. 6a) and rPFO $_{\text {C-ter }}$ (Fig. 6b) immunized mice were found to be higher on day 14 after immunization and increased further on day 21 , day 35 , and day 49 after the administration of the boosters. Although the IgG level against the rPFOC-ter was lower than that observed with the WTrPFO (indicated by relatively lower absorbance), the IgG levels remained significantly higher than that of pre-immune serum. The endpoint titers of the anti-WTrPFO antisera drawn on day 14 , day 21 , and day 35 and day 49 post-immunization were determined to be much greater than 1:20,000 (day 14), 1:80,000 (day 21), and $1: 160,000$ (day 35 and day 49) as the absorbance remained significantly higher $(p \leq 0.001)$ than that obtained with preimmune serum. On the other hand, the endpoint titers for anti-rPFOC-ter were determined to be '1: 10,000'1: 20,000, '1: 80,000 , and ' $1: 160,000$ on day 14 , day 21 , day 35 , and day 49 post-immunization, respectively.

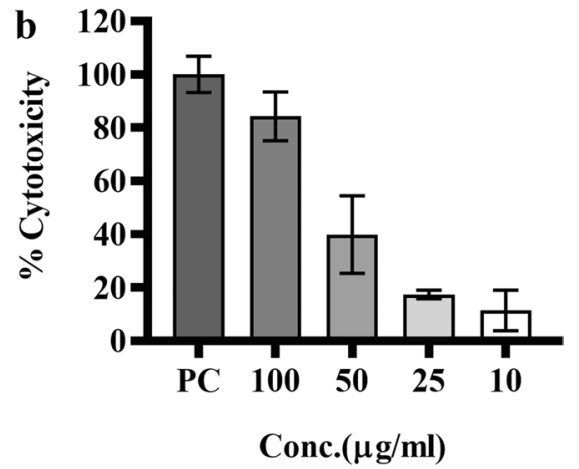

ferent concentrations $(10-100 \mu \mathrm{g} / \mathrm{ml})$ of WTrPFO (in triplicates) at $37{ }^{\circ} \mathrm{C}$ for $24 \mathrm{~h}$ in $5 \% \mathrm{CO} 2$ humidified atmosphere. LDH release was taken as a measure of cytotoxicity, and the absorbance at $490 \mathrm{~nm}$ was considered as an indicator of lysis. Percentage cytotoxicity was calculated with respect to lysis caused by lysis buffer included as a positive control (PC) and considered to cause $100 \%$ lysis. Data represent mean \pm SD of three independent experiments performed in triplicates 


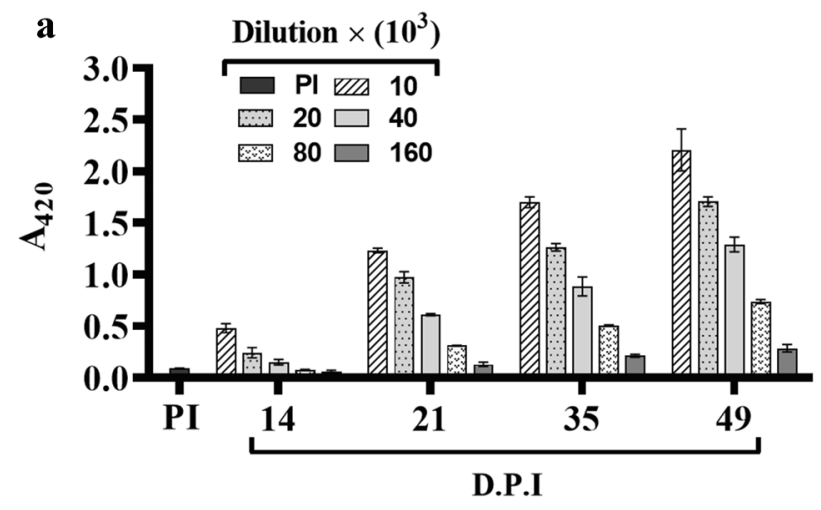

Fig. 6 Antibody titers of the anti-WTrPFO and anti-rPFO ${ }_{\mathrm{C}-\text { ter }}$ antisera. Different dilutions of the antisera drawn on different days post-immunization (D.P.I.) from mice immunized with WTrPFO (a) or $\mathrm{rPFO}_{\mathrm{C}-\text { ter }}$ (b) were subjected to ELISA for the determination of antigen-specific antibody titers. Anti-mouse Fc-specific alkaline phosphatase-conjugated antibody was used as a secondary antibody. Endpoint titers of the anti-WTrPFO antisera were determined to be $\geq 1: 20,000$ on day $14, \geq 1: 80,000$ on days 21 and 35 , and $\geq 160,000$

\section{Specificity and cross-reactivity analysis of the antisera}

Immunoblot analysis of the induced cell lysates of the $E$. coli BL21( $\lambda \mathrm{DE} 3)$ plysS cells harboring $\mathrm{pET} 22 . P F O_{\mathrm{wt}}$ and pET22. $P F O_{C-\text { ter }}$ showed that the anti-WTrPFO antiserum collected on day 35 (a week after the second booster) detected a single band corresponding to the recombinant protein in the induced cell lysates (Fig. 7a, lane I, rPFO). The absence of the band in the uninduced cell lysate indicates the specificity of the anti-WTrPFO antibodies (Fig. 7a, lane UI, rPFO). Surprisingly, the anti-WTrPFO

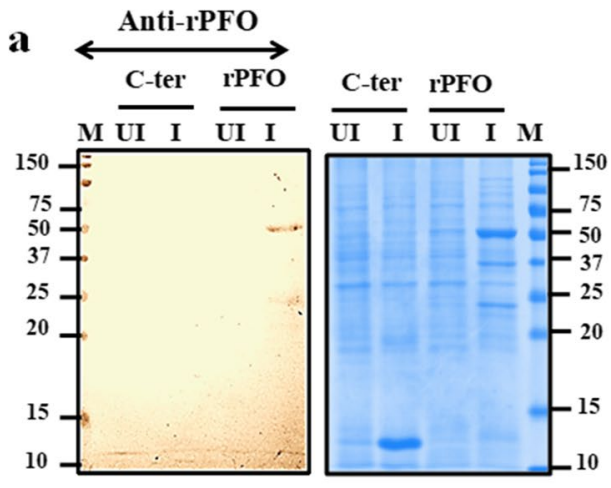

Fig. 7 Western blot analysis. Antigen specificity of the a anti$\mathrm{WTrPFO}$ and $\mathbf{b}$ anti- $\mathrm{rPFO}_{\mathrm{C}-\text { ter }}$ antisera was determined by immunoblot analysis. Ten micrograms of the uninduced (UI) and induced (I) cell lysates of the $E$. coli $\mathrm{BL} 21(\lambda \mathrm{DE} 3)$ pLysS cells expressing WTrPFO (rPFO) or $\mathrm{rPFO}_{\mathrm{C} \text {-ter }}(\mathrm{C}$ - ter) were resolved on SDS-PAGE and immunoblotted either with anti-WTrPFO antiserum (anti- rPFO, panel a) or anti-rPFO ${ }_{\mathrm{C} \text {-ter }}$ antisera (anti-C-ter, panel b) at 1:10,000

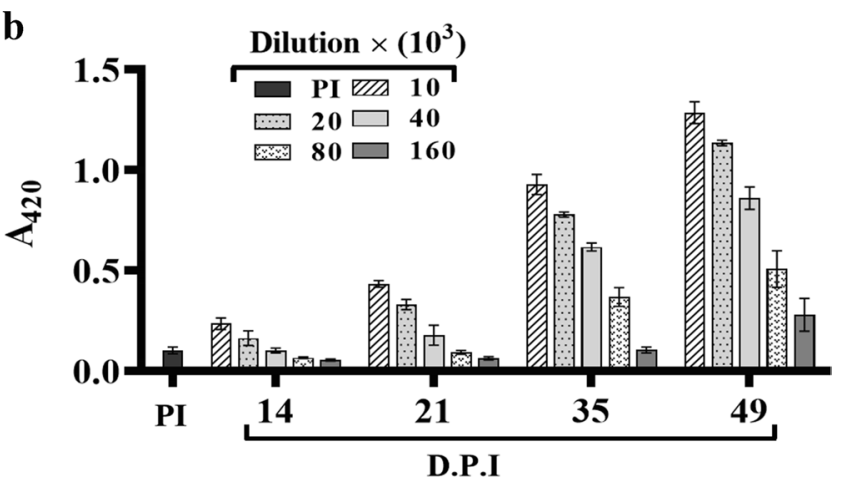

on day 49 post-immunization. Endpoint titers for anti-rPFO ${ }_{\mathrm{C}-\text { ter }}$ antisera were determined to be ' 1 : $10,000,{ }^{\prime} 1$ : $20,000,{ }^{\prime} 1$ : 80,000 , and ' 1 : 160,000 on days $14,21,35$, and 49 post-immunization, respectively. Absorbance at $420 \mathrm{~nm}$ (A420) depicts mean \pm S.D. of pooled antisera samples ( $n=5$ mice per group) analyzed in triplicates. One-way ANOVA was used to determine the significant difference between PI and different antisera dilutions

antiserum could not detect the $\mathrm{rPFO}_{\mathrm{C}-\text { ter }}$ protein (Fig. 7a, lane I, C-ter) in the cell lysates of $E$. coli BL21( $\lambda \mathrm{DE} 3)$ plysS expressing $\mathrm{rPFO}_{\mathrm{C} \text {-ter }}$. Likewise, the antigen specificity and the cross-reactivity analysis of anti-rPFO $\mathrm{C}_{\text {-ter }}$ antiserum were analyzed by immunoblotting the induced cell lysates of the $E$. coli BL21( $\lambda$ DE3)plysS expressing WTrPFO. Detection of a single band at $\sim 54 \mathrm{kDa}$ position revealed that the anti-rPFO $\mathrm{C}_{\mathrm{C} \text {-ter }}$ antiserum (raised against only the C-terminal of the PFO) could specifically cross-react with the full-length protein (Fig. 7b, lane I, $\mathrm{rPFO}$ ). Detection of a band at $\sim 14 \mathrm{kDa}$ position in the cells

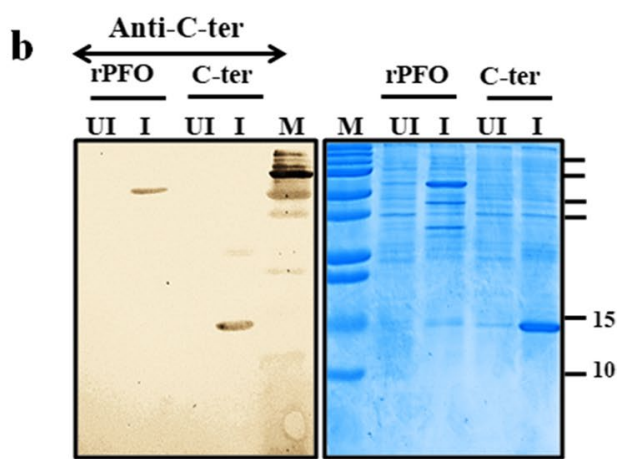

dilution. Alkaline phosphatase (AP)-conjugated goat anti-mouse/ anti-rabbit antibody $(1: 10,000)$ dilution was used as a secondary antibody. In both the panels, the image on the left shows the parallelly run SDS-PAGE of the same lysates stained with Coomassie blue stain. Lane $\mathrm{M}$ denotes the pre-stained protein molecular weight $(\mathrm{kDa})$ marker 
expressing the $\mathrm{rPFO}_{\mathrm{C} \text {-ter }}$ revealed the antigen specificity of the anti-rPFO $\mathrm{C}_{\mathrm{C} \text {-ter }}$ antiserum (Fig. 7b, lane I, C-ter).

\section{Analysis of immune response}

\section{Antibody isotyping in the antiserum}

Different $\operatorname{IgG}$ isotypes, namely, $\operatorname{IgG} 1, \operatorname{IgG} 2 \mathrm{a}$, and $\operatorname{IgG} 2 \mathrm{~b}$, in the anti-WTrPFO and anti-rPFO $\mathrm{C}_{\text {-ter }}$ antisera collected on day 21 , day 35 , and day 49 post-immunization were assayed to determine the type of immune response generated against the test proteins (Fig. 8). Significantly elevated levels of all the three isotypes were observed in the antisera generated against WTrPFO (Fig. 8a) and rPFOC-ter (Fig. 8b) compared to the respective pre-immune sera. The ratios of $\operatorname{IgG} 1 / \operatorname{IgG} 2 \mathrm{a}$ and $\operatorname{IgG} 1 / \operatorname{IgG} 2 \mathrm{~b}$ in the anti-WTrPFO collected on day 21 , day 35 , and day 49 were $>1$, reflecting the Th2-biased immune response. The ratio of $\mathrm{IgG} 1 / \operatorname{IgG} 2 \mathrm{a}$ in the anti-rPFO $\mathrm{C}_{\mathrm{C} \text { ter }}$
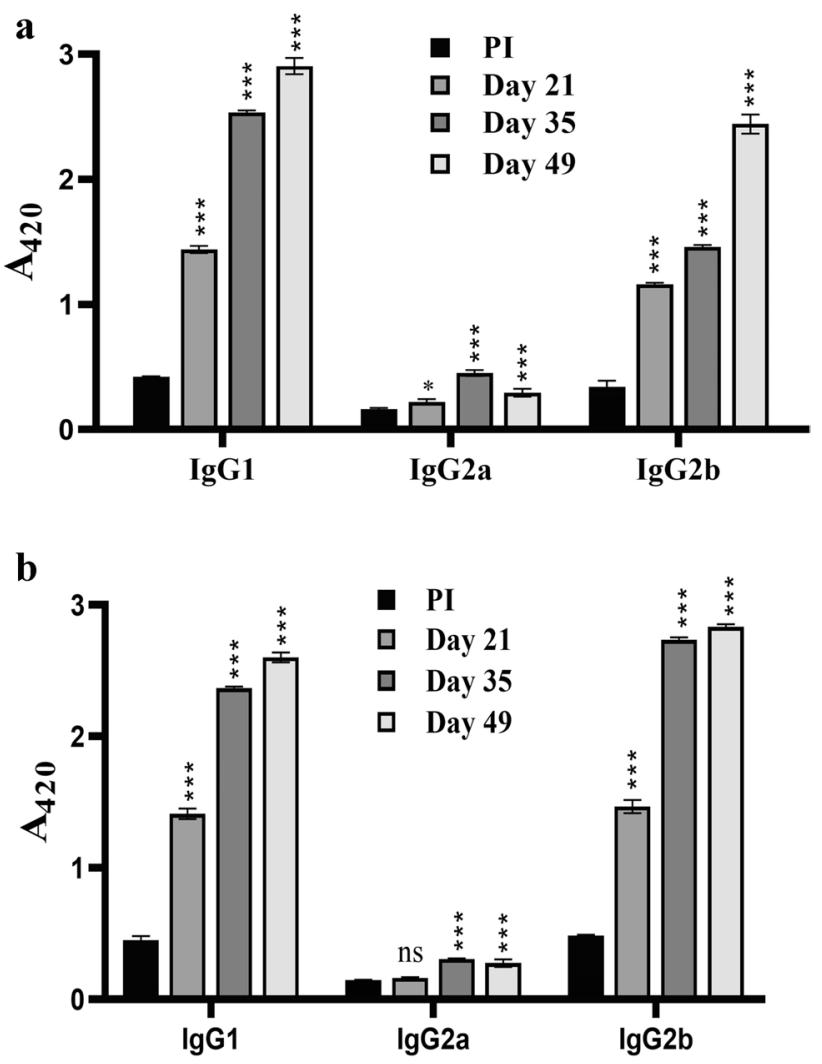

Fig. 8 Determination of antibody isotypes. The anti-WTrPFO (a) and anti-PFO $\mathrm{C}_{\mathrm{C} \text {-ter }}(\mathbf{b})$ antisera, collected on days 21,35 , and 49 postimmunization, were analyzed for different $\mathrm{IgG}$ isotype levels by ELISA using respective HRP-conjugated isotype-specific secondary antibodies. Pre-immune (PI) serum was included as control. Data represent mean \pm S.D. of absorbance $\left(\mathrm{A}_{420}\right)$ of analyses performed in triplicates. The significance of the difference in the different isotypes in the antisera collected on different days with respect to PI was determined using a one-way ANOVA and is denoted as $p \leq 0.05\left(^{*}\right)$, $p \leq 0.01(* *)$, and $p \leq 0.001(* * *)$ antisera was determined to be much ' 1 at all study intervals (8.67, 7.89 , and 8.64 on day 21 , day 35 , and day 49 , respectively), whereas the ratio of $\mathrm{IgG} 1 / \mathrm{IgG} 2 \mathrm{~b}$ was determined to be slightly $<1(0.962,0.867$, and 0.925 on day 21 , day 35 , and day 49 , respectively), suggesting predominantly Th2-biased mixed immune response.

\section{Analysis of $\mathrm{T}$ cell responses including $\mathrm{T}$ cell memory and $\mathrm{T}$ cell polarization against WTrPFO and rPFOC-ter}

In vitro proliferation of the splenocytes isolated from the mice immunized with the WTrPFO and $\mathrm{rPFO}_{\mathrm{C} \text {-ter }}$ and stimulated with the respective proteins resulted in significantly higher proliferation than that stimulated with PBS at all study intervals (Fig. 9a and b). No increase in the proliferation was noted when the splenocytes isolated from the PBS-immunized mice were stimulated with the test proteins. The significant increase in proliferation with $\mathrm{WTrPFO}$ stimulation of the respective splenocytes was determined to be at $p \leq 0.05, p \leq 0.01$, and $p \leq$ 0.001 at 24 h, 48 h, and 72 h, respectively (Fig. 9a). The significance levels of change with $\mathrm{rPFO}_{\mathrm{C} \text {-ter }}$ were found to be $(p$ $\leq 0.01$ ) at all the three intervals post-stimulation (Fig. 9b). The stimulation index of the WTrPFO- and $\mathrm{rPFO}_{\mathrm{C}-\text { ter }}$-stimulated splenocytes was determined to be 1.4 and 2.08, respectively, which was noticeably higher than that of the control splenocytes $(\sim 1.15)$, indicating significant $\mathrm{T}$ cell activation and proliferation in response to antigens.

The type of $\mathrm{T}$ cell immune response (evaluated by antibody isotype analysis) was further confirmed by assessing IL-4 (Th2 marker) and IFN- $\gamma$ (Th1 marker) levels in the splenocyte culture supernatants post-stimulation of splenocytes isolated from mice immunized with the proteins. A significant increase ( $p \leq 0.05-0.01)$ in both IL-4 and IFN- $\gamma$ levels in splenocytes isolated from WTrPFO (Fig. 10a and c) and $\mathrm{rPFO}_{\mathrm{C}-\text { ter }}$ (Fig. 10b and d) immunized mice stimulated with the respective proteins demonstrated that both proteins are able to generate mixed $\mathrm{T}$ cell immune response at all the time points. It was noted that at $48 \mathrm{~h}$, the increase in IL-4 levels was more prominently indicative of $\mathrm{Th} 2$ immune response; in the WTrPFO-stimulated splenocytes isolated from the immunized mice, at $72 \mathrm{~h}$, there was a shift to $\mathrm{Th} 1$ response as IFN- $\gamma$ levels increased further with a concomitant decrease in IL-4 levels in the splenocytes isolated from the WTrPFO (Fig. 10a and c) and $\mathrm{rPFO}_{\mathrm{C} \text {-ter }}$ (Fig. 10b and d) immunized mice, suggesting a shift to Th1-biased mixed immune response at later intervals.

\section{Neutralization ability of the anti-WTrPFO and anti-rPFO ${ }_{\text {-ter }}$ of the hemolytic and cytotoxic activity of the WTrPFO}

Pre-incubation of WTrPFO at $2 \mu \mathrm{g} / \mathrm{ml}$ (that caused $80 \%$ hemolysis) with different dilutions $(50-5 \%)$ of both the 


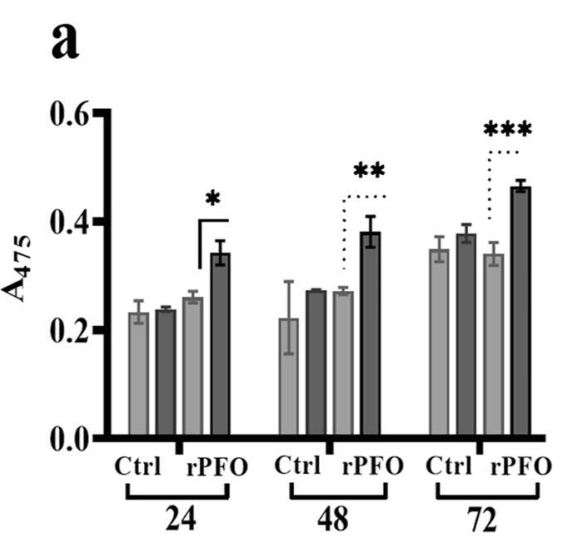

Fig. 9 Assessment of in vitro $\mathrm{T}$ cell proliferation response. Splenocytes $\left(1 \times 10^{5}\right.$ cell/well in $\left.100 \mu \mathrm{l}\right)$ isolated from mice immunized with $\mathrm{WTrPFO}$ (a) and $\mathrm{rPFO}_{\mathrm{C}-\mathrm{ter}}$ (b) (ip; $30 \mu \mathrm{g} /$ mice) were stimulated with the respective protein $(20 \mu \mathrm{g} / \mathrm{ml}$, stimulated $)$ and vehicle $(1 \times \mathrm{PBS}$, unstimulated). "Ctrl" in both the panels indicates splenocytes isolated from mice immunized with $1 \times \mathrm{PBS}$ (control) and stimulated with either WTrPFO (panel a) or $\mathrm{rPFO}_{\mathrm{C} \text {-ter }}$ (panel b) or PBS (unstimu- lated). Splenocyte proliferation was measured by XTT assay at different time intervals post-stimulation. Data represent the mean \pm S.D. of 3 independent experiments performed in triplicates. Statistical significance ( $p$ value) was calculated with respect to PBS-stimulated splenocytes of the same group using the Student's two-tailed $t$-test. $p \leq 0.05(*), p \leq 0.01(* *)$, and $p \leq 0.001(* * *)$
anti-WTrPFO and anti-rPFO $\mathrm{C}_{\mathrm{C}-\mathrm{ter}}$ antisera prior to addition to mice RBCs $\left(2.5 \times 10^{6}, 50 \mu \mathrm{l}\right)$ resulted in inhibition of hemolytic activity to a great extent, indicating the excellent inhibitory capacity of both antisera (Fig. 11a and b). Inhibition of the hemolytic activity of the WTrPFO was maximum (more than $90 \%$ ) at the dilution of $25 \%$ of both the antisera. Incubation of the toxin (WTrPFO) with other dilutions of the antisera $(50 \%, 10 \%$, and 5\%) also resulted in more than $80 \%$ inhibition of hemolytic activity. No significant inhibition ( $4.56 \%$ ) was observed when the WTrPFO was pre-incubated with neat pre-immune serum.

Pre-incubation of the WTrPFO with the antisera generated against both the $\mathrm{WTrPFO}$ and $\mathrm{rPFO}_{\mathrm{C}-\text { ter }}$, at all the dilutions (1:10-1: 10,000), was able to neutralize the cytotoxicity of the purified WTrPFO $(100 \mu \mathrm{g} / \mathrm{ml})$ significantly towards the mice peritoneal macrophages (Fig. $11 \mathrm{c}$ and d). The neutralization capacity of the antisera was determined as the percentage of reduced cytotoxicity of the purified WTrPFO pre-incubated with different dilutions $(1: 10-1: 10,000)$ of each antiserum, with respect to the cells incubated with the WTrPFO alone (considered as $100 \%$ ). Interestingly, the neutralization capacity of neat anti-WTrPFO and anti- $\mathrm{rPFO}_{\mathrm{C}-\text { ter }}$ was slightly lower $\sim 40$ $\%$ and $\sim 49 \%$ compared to other dilutions of the antisera $(1: 10-1: 10,000 ; \geq 80 \%)$ with constant WTrPFO concentration $(100 \mu \mathrm{g} / \mathrm{ml})$. The anti-rPFO $\mathrm{C}_{\text {-ter }}$ antiserum also efficiently neutralized the WTrPFO cytotoxicity ( $\geq 80 \%)$ at all the dilutions. Maximum neutralization ( $96 \%$ ) was achieved when the WTrPFO was pre-incubated with the anti- $\mathrm{PFFO}_{\mathrm{C}-\mathrm{ter}}$ antiserum at a dilution of 1:500 that indicated its equivalence zone.

\section{Discussion}

Different types of C. perfringens strains cause various diseases in humans and animals, attributed to single or multiple toxins secreted by different strains. The bacterium is ubiquitously present in the environment and is highly pathogenic. It has a high proliferation rate and results in the death of animals either within hours of the appearance of symptoms or without any clinical symptoms. Though it is susceptible to several antibiotics, including penicillin and clindamycin, its rapid proliferation rate results in death without a premonitory sign making antibiotics ineffective [16]. This endorses the development of vaccines against the toxins involved in the pathogenesis of $C$. perfringens to counteract the infection. Though attempts have been made to develop vaccines against different toxins secreted by a specific type, these can be used against a specific type of $C$. perfringens. Therefore, a toxin secreted by all types is likely to assist in protecting the animals from all types of $C$. perfringens. PFO is one of the toxins of $C$. perfringens that contributes to the pathogenesis of $C$. perfringens and is believed to be produced by all the isolates [11]. Although PFO is not the main diseasecausing toxin, it acts synergistically with $\alpha$-toxin in calves, causing myonecrosis and necrohemorrhagic enteritis [12, 13]. PFO has also been reported to augment the toxicity of $\varepsilon$-toxin in a mouse model for enterotoxaemia caused by $C$. perfringens type $\mathrm{D}$, a disease of goat and sheep. These data highlight the importance of PFO in supporting the outbreak of different $C$. perfringens-associated 

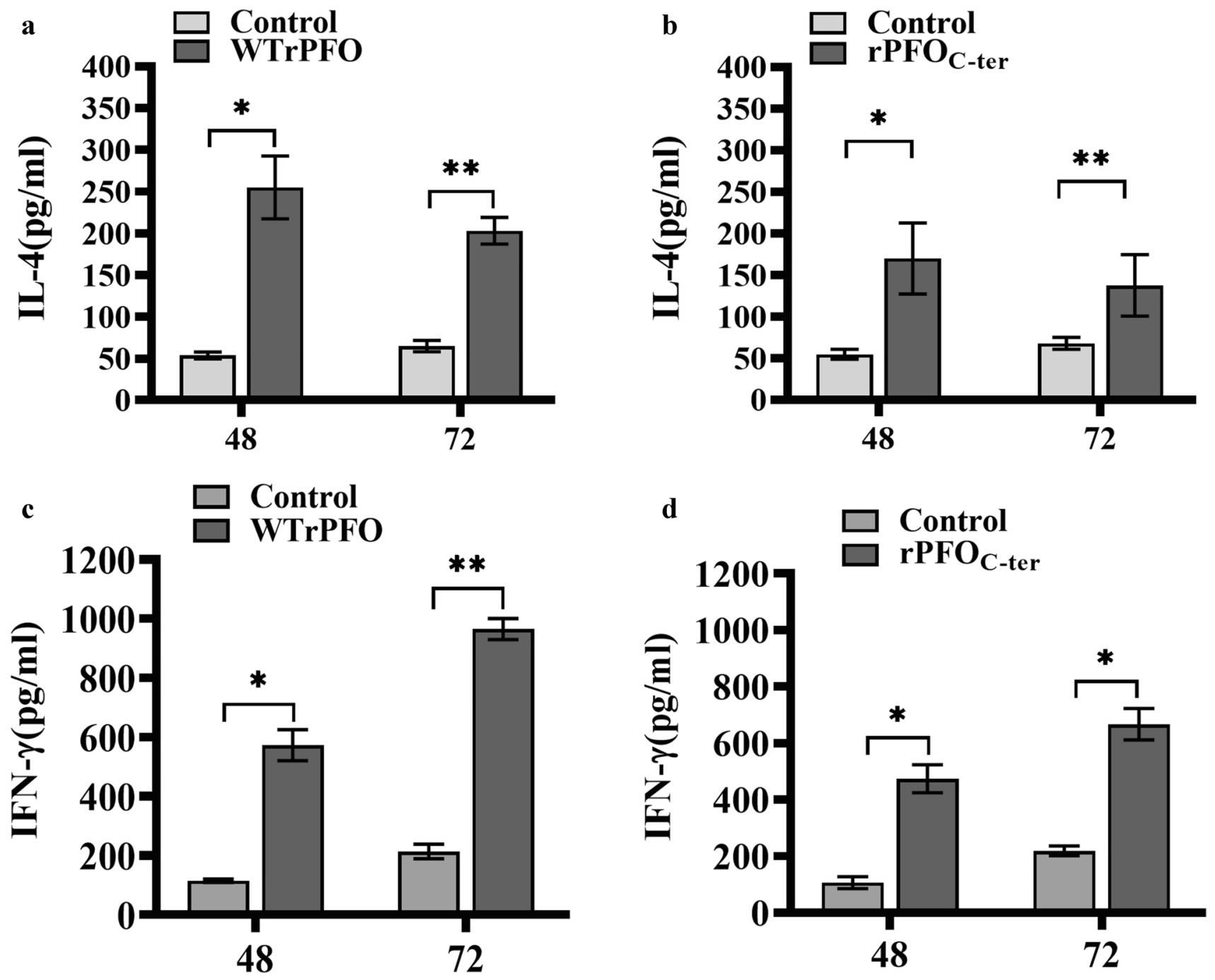

Fig. 10 Analysis of T cell immune response (Th1 and Th2 type) by cytokine ELISA. a and b IL-4 levels (pg/ml) in the culture supernatants (harvested at different time points) of splenocytes isolated from the WTrPFO and rPFOC-ter immunized mice and stimulated with the respective proteins, respectively. c and $\mathbf{d}$ IFN- $\gamma$ levels in the culture supernatants (harvested at different time points) of splenocytes iso-

diseases [14], making it an attractive vaccine candidate that could be used in combination with the existing vaccine preparation against the toxin secreted by a specific type. Earlier reports by Goossen et al. demonstrated that the $\alpha$-toxin and PFO are the most immunogenic proteins in vaccine preparations, and immunization with the native toxin(s) or toxoids confers protection against the toxininduced necrotic lesions in the intestinal loop model [19]. In vitro neutralizing capacity of a PFO derivative with a single amino acid substitution $\left(\mathrm{PFO}^{\mathrm{L} 491 \mathrm{D}}\right)$ against the hemolytic activity and cytotoxic effect of PFO in horse red blood cells and bovine endothelial cells has been reported [37]. However, detailed in vivo immune response analysis against these proteins has not been reported. Since the

lated from the WTrPFO and $\mathrm{rPFO}_{\mathrm{C}-\mathrm{ter}}$ immunized mice and stimulated with the respective proteins. Control in each panel represents the cytokine produced by splenocytes of PBS-immunized mice, stimulated with respective proteins. Data represent the mean \pm SD of three experiments performed in triplicates. The statistical significance $(p$ value) levels are as follows: $p \leq 0.05(*), p \leq 0.001(* *), p \leq 0.001(* * *)$

type of immune response generated against an antigen is critical in inducing a long-lasting protective immune response, we carried out the present study to assess the vaccine potential of soluble recombinant PFO (WTrPFO). The native toxins are generally not considered safe for vaccine development, as these can cause local tissue damage at the administration site. Therefore, the vaccination dose needs to be closely monitored not to cause adverse effects on the organism. Other approaches, including genetically modified toxins by site-directed mutagenesis or by using a non-toxic immunogenic fragment of the toxin, could be used to generate an effective and protective immune response that has been reported with the $\mathrm{C}$-terminal domain of $\alpha$-toxin [20, 38-40]. In the present study, we 

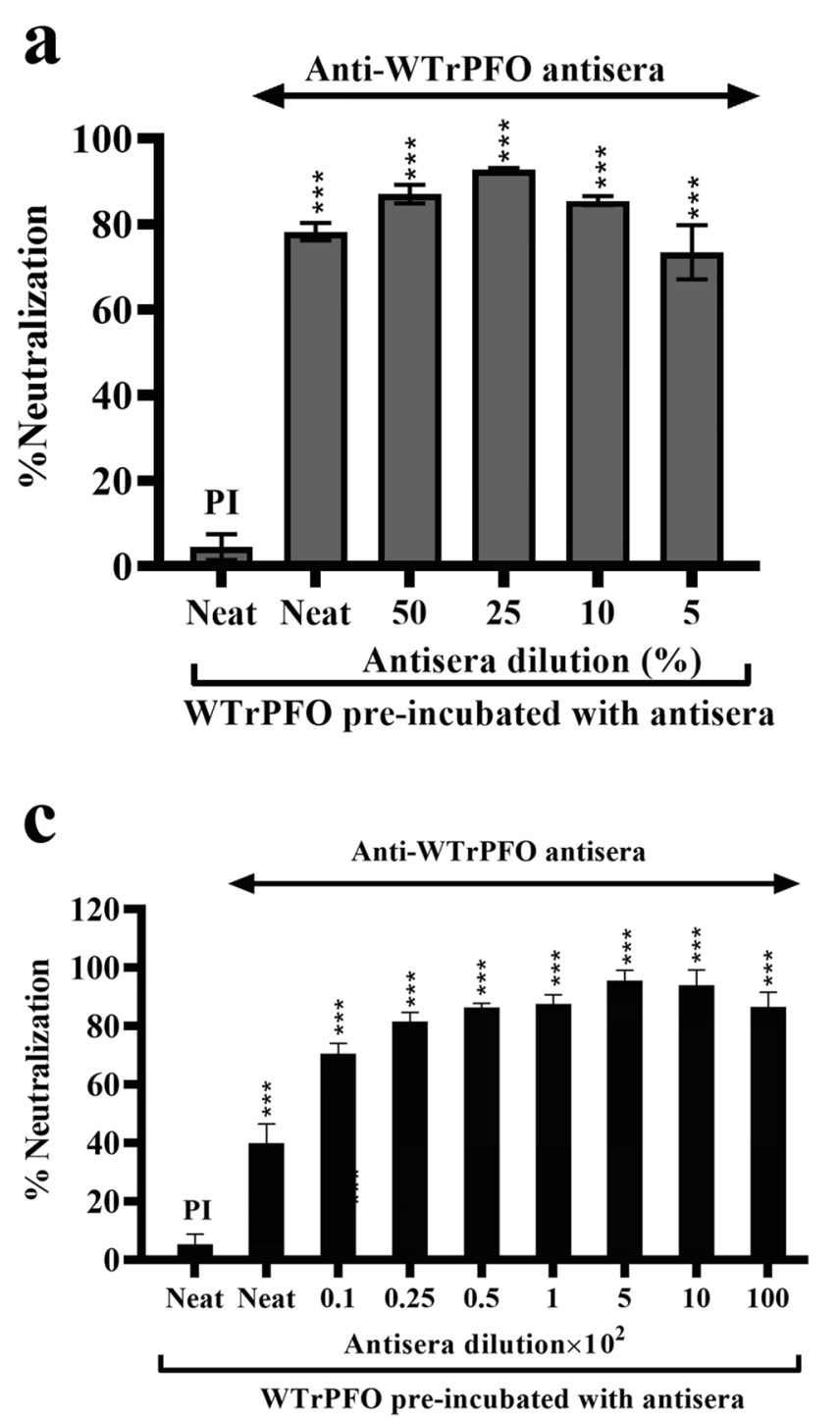

Fig. 11 Neutralization potential of the anti-WTrPFO and anti$\mathrm{rPFO}_{\mathrm{C}-\text { ter }}$ antisera. (a and b) Neutralization of hemolytic activity of WTrPFO. The WTrPFO $(2.0 \mu \mathrm{g} / \mathrm{ml})$ was incubated with different dilutions of the antisera (neat and 50-5\%) in a total volume of $150 \mu \mathrm{l}$ for $1 \mathrm{~h}$ at $37{ }^{\circ} \mathrm{C}$ before addition to the mice RBCs $\left(2.5 \times 10^{6}\right.$ cells in $50 \mu \mathrm{l}$ ). After incubation at $37^{\circ} \mathrm{C}$ for $60 \mathrm{~min}$, the absorbance of the supernatant was measured at $540 \mathrm{~nm}$ for released hemoglobin. WTrPFO $(20 \mu \mathrm{g} / \mathrm{ml})$ pre-incubated with vehicle $(1 \times \mathrm{PBS})$ was included as positive control and considered to cause $100 \%$ hemolysis. WTrPFO pre-incubated with PI (neat) was included as a negative control. Percentage inhibition of hemolysis was calculated with respect to the absorbance obtained with WTrPFO incubated with $1 \times$ PBS. (c and d) Neutralization of cytotoxic activity of WTrPFO in mice peritoneal macrophages. Mice peritoneal macrophages

targeted the receptor-binding C-terminal domain of the PFO, which is crucial for initiating oligomer formation in the membrane by recognizing and binding the toxin to the host cell membrane [41]. The two proteins were produced through recombinant routes, and a comparative analysis of the immune response generated against
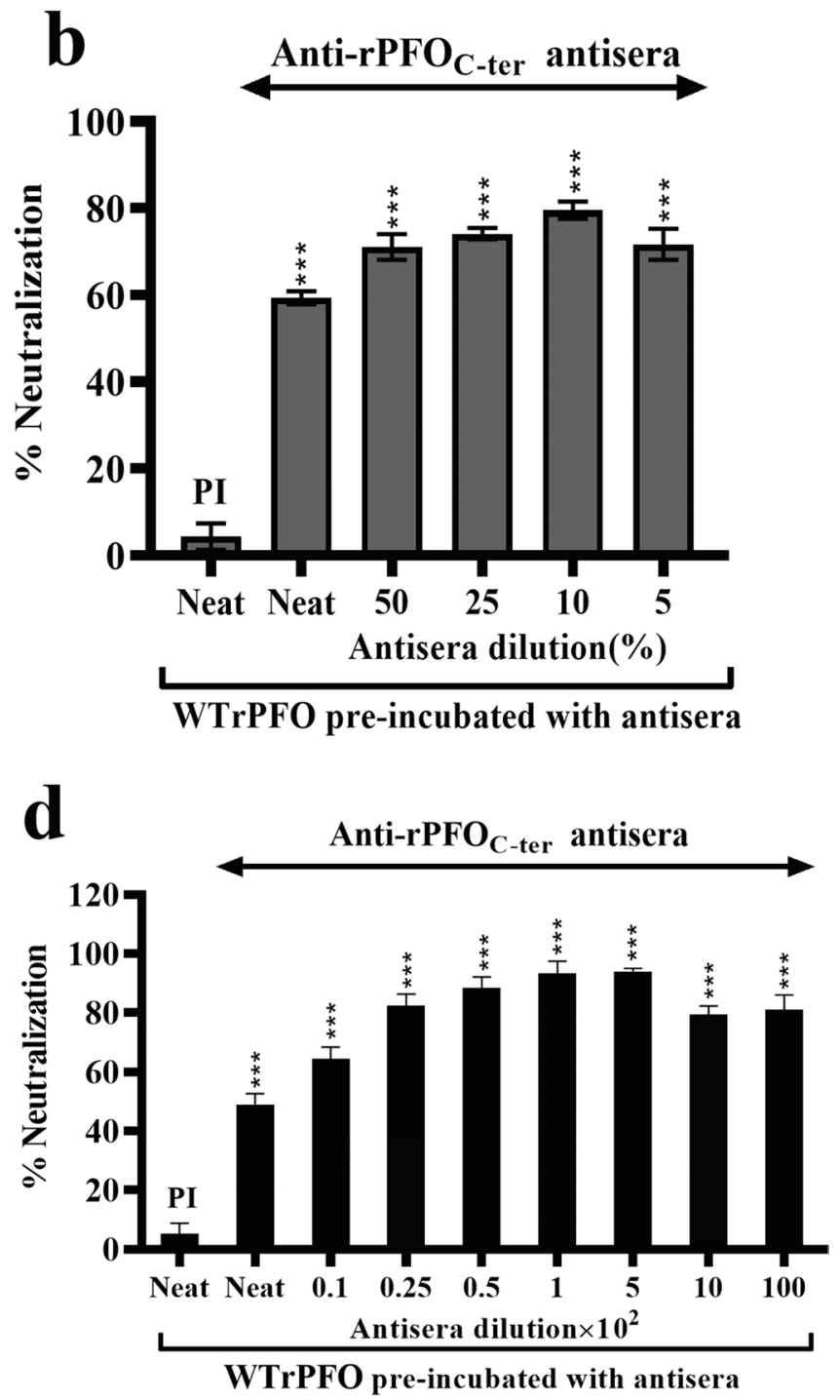

$\left(5 \times 10^{4}\right.$ macrophages/100 $\left.\mu \mathrm{l}\right)$ were treated with $\mathrm{WTrPFO}(100 \mu \mathrm{g} /$ $\mathrm{ml})$ pre-incubated with different dilutions $(1: 10,1: 25,1: 50,1: 100$, $1: 500,1: 1000$, and $1: 10,000$ ) of the anti-WTrPFO (panel c) and anti- $\mathrm{rPFO}_{\mathrm{C}-\text { ter }}$ (panel d) for $1 \mathrm{~h}$ at $37{ }^{\circ} \mathrm{C}$. The cells were then incubated at $37{ }^{\circ} \mathrm{C}$ for $24 \mathrm{~h}$ in $5 \% \mathrm{CO} 2$ atmosphere, followed by $\mathrm{LDH}$ release. WTrPFO pre-incubated with PI (neat) was considered as a negative control. Percentage neutralization was calculated with respect to $\mathrm{LDH}$ released by the cells treated with $\mathrm{WTrPFO}$ incubated with $1 \times$ PBS, taken as $100 \%$ cytotoxicity. Data represent mean \pm SD of neutralization percentage of experiments performed in triplicates. Ordinary one-way ANOVA was used to determine the significance of neutralization ability of the antiserum with respect to control cells treated with WTrPFO incubated with PI. $p \leq 0.05\left(^{*}\right), p \leq 0.001(* *)$, $p \leq 0.001$ (***)

these proteins was carried out. We expressed the WTrPFO and $\mathrm{rPFO}_{\mathrm{C}-\text { ter }}$ using heterologous host E. coli for analyzing their immunogenic and neutralizing potential. A tight and intense band of WTrPFO and rPFOC-ter only in the induced cell lysates at the expected positions ( $\sim 54 \mathrm{kDa}$ and $\sim 14 \mathrm{kDa}$, respectively) established the tight regulation of 
the $\mathrm{T} 7$ expression system. Initial attempts to express the proteins at $25{ }^{\circ} \mathrm{C}$ and $37{ }^{\circ} \mathrm{C}$ resulted in the expression of the two proteins as insoluble proteins. This is expected as higher expression of recombinant protein(s) without the signal sequence results in misfolding of the protein in the cytoplasm and leads to aggregation to form inclusion bodies. Another recombinant cytolysin, such as the C-terminal domain of streptolysin $\mathrm{O}$, has also been reported to express as inclusion bodies [42]. For biologically active protein, it is important to express the protein as a soluble protein (native form). Therefore, optimization of expression conditions was carried out to direct the expression to soluble fraction. Induction of expression at a lower temperature for a prolonged period led to the expression of these two proteins predominantly in soluble fraction. Significantly higher yields of the purified recombinant proteins $(70 \mathrm{mg} / 1$ and $75 \mathrm{mg} / \mathrm{l}$ for WTrPFO and $\mathrm{rPFO}_{\mathrm{C} \text {-ter }}$, respectively) were obtained compared to $15 \mathrm{mg} / \mathrm{l}$ reported by Tweten, who purified the protein from a clone identified from a C. perfringens genome library in bacteriophage $\lambda$ [34]. Tweten's PFO clone from the genomic library contained the signal sequence and directed the expression of rPFO in the periplasm, resulting in a significantly lower yield [34]. In the present study, the protein was expressed without the signal sequence and with a histidine tag which facilitated a single-step purification, thus improving the yield. This is important as higher production of the protein is desirable for the assessment of its biological activity as well as vaccine potential.

The WTrPFO purified from the soluble fraction was biologically active, and its hemolytic activity $\left(10^{5} \mathrm{HU} / \mathrm{mg}\right)$ was comparable with that reported by Tweten [34]. Furthermore, sufficient cytotoxicity (close to SDS, included as positive control) observed with WTrPFO in mice peritoneal macrophages confirmed that histidine tag did not affect its biological activity, and the structural conformation of the soluble WTrPFO was similar to that of native PFO. On the other hand, as expected, the $\mathrm{rPFO}_{\mathrm{C}-\text { ter }}$ did neither cause any hemolysis of the mice RBCs nor was it found to be cytotoxic to mice peritoneal macrophages, confirming its non-toxic nature (data not shown).

Immunization of mice with the WTrPFO and non-toxic $\mathrm{rPFO}_{\mathrm{C}-\mathrm{ter}}$ emulsified with Freund adjuvant resulted in robust immune response, evidenced by very high antigenspecific antibody titers in the antisera generated against the two proteins. Although the endpoint titers of the $\mathrm{rPFO}_{\mathrm{C}-\mathrm{ter}}$ antiserum appeared to be slightly lower than the fulllength WTrPFO, the antigen-specific immune response (determined by immunoblotting) of the anti-rPFO $\mathrm{C}_{\mathrm{C} \text {-ter }}$ was as strong as the anti-WTrPFO. Effective and specific cross-reactivity of antiserum raised against the nontoxic $\mathrm{PFFO}_{\mathrm{C} \text {-ter }}$ with the WTrPFO toxin suggested that the antibodies present in the anti- $\mathrm{rPFO}_{\mathrm{C} \text {-ter }}$ could neutralize
WTrPFO toxicity and thus can serve as a non-toxic vaccine candidate.

Further, for a vaccine candidate to act effectively, the generation of immune memory is a desirable criterion so that the immune cells can get activated upon exposure to the respective pathogen. The stimulation of lymphocytes isolated from WTrPFO and $\mathrm{rPFO}_{\mathrm{C} \text {-ter }}$ immunized mice with the respective proteins resulted in enhanced proliferation of splenocytes, indicating that both the proteins could generate $\mathrm{T}$ cell memory in mice after immunization. An increase in the $\operatorname{IgG} 1, \operatorname{IgG} 2 \mathrm{a}$, and $\operatorname{IgG} 2 \mathrm{~b}$ with a ratio of $\operatorname{IgG} 1 / \operatorname{IgG} 2 \mathrm{a}$ more than 1 and $\operatorname{IgG} 1 / \operatorname{IgG} 2 \mathrm{~b}$ almost close to 1 indicated a Th2-biased immune response. The cytokine ELISA of the culture supernatants of the splenocytes isolated from the $\mathrm{WTrPFO}$ and $\mathrm{rPFO}_{\mathrm{C}-\text { ter }}$ immunized mice stimulated with the respective protein also confirmed the Th2-biased immune response as a significant increase in both IFN- $\gamma$ (a marker of Th1-type immune response) and IL-4 (a marker of Th2type immune response) was noted which again confirmed mixed immune response. A vaccine that generates a mixed immune or Th1 response is considered a better candidate than that stimulates Th2-type response [43, 44]. Thus, both the $\mathrm{WTrPFO}$ and $\mathrm{rPFO}_{\mathrm{C} \text {-ter }}$ that generated mixed immune response are likely to prove promising vaccine candidates against the PFO toxicity of all types of $C$. perfringens strains.

PFO, known to cause hemolysis, is also responsible for C. perfringens-dependent macrophages cytotoxicity by resisting the $C$. perfringens to be killed by phagocytosis of macrophages [45]. Therefore, these two assays were used for assessing the toxin neutralization ability of the antisera. The ability of the anti-WTrPFO antiserum and anti-rPFOC-ter antiserum to neutralize the hemolytic activity and cytotoxicity of WTrPFO confirmed that the antibodies present in these antisera are neutralizing type. Surprisingly, the hemolytic inhibition by neat and antisera diluted two folds $(50$ $\%$ ) appeared less than the 4 folds diluted antiserum (25\%), despite higher concentrations of antibodies in these compared to $25 \%$ diluted antisera dilutions. Similarly, the neutralization capacity of neat anti-WTrPFO and anti-rPFO $\mathrm{C}_{\mathrm{C} \text {-ter }}$ antisera against the cytotoxic effect of WTrPFO was found to be lower ( $40 \%$ and $\sim 49 \%$, respectively), when compared to other dilutions of the antisera $(1: 10-1: 10,000 ; \geq 80 \%)$ keeping the amount of the WTrPFO constant $(100 \mu \mathrm{g} / \mathrm{ml})$. The neutralization percentage of anti-WTrPFO was $\geq 80 \%$ at the dilutions of 1:250-1:10,000 and attained maximum neutralization (99\%) at the dilution fraction 1:500 that indicated the equivalence zone of antigen-antibody interaction. Higher neutralizing capacity of the diluted antiserum compared to neat antiserum could be attributed to the Lattice theory that explained the precipitation reactions in fluid media in which antigen-binding sites in concentrated polyclonal antibodies 
became saturated, reducing their antigen-binding ability [46].

Comparable neutralization $(\sim 90 \%)$ of the WTrPFO cytotoxicity by both the anti-WTrPFO and anti-rPFO ${ }_{\mathrm{C}-\text { ter }}$ antisera in mice peritoneal macrophages demonstrates the effectiveness of non-toxic $\mathrm{rPFO}_{\mathrm{C} \text {-ter }}$ in negating the $\mathrm{PFO}$ toxicity. The same can be employed as a promising alternative to native PFO toxin in combination with the nontoxic C-terminal domain of alpha-toxin or another nontoxic alternative of main virulent disease-causing toxins of different types of $C$. perfringens to generate a protective immune response against the bacterium. The present study thus reports a comparative analysis of the immune response generated against the WTrPFO and non-toxic $\mathrm{C}$-terminal domain of PFO. Despite relatively lower $\mathrm{IgG}$ levels in the anti-rPFO $\mathrm{C}_{\mathrm{C} \text {-ter }}$ antiserum, it could specifically recognize the full-length PFO and neutralize the hemolytic and cytotoxic activity of the PFO in vitro.

Thus, the present study reports recombinant expression and purification of the full-length $\mathrm{PFO}$ of $C$. perfringens and its C-terminal receptor-binding domain as soluble proteins. Comparative analysis of the immunogenicity and antigenicity of both the WTrPFO and its deletion variant (i.e., C-terminal receptor-binding domain, $\mathrm{rPFO}_{\mathrm{C}-\text { ter }}$ ) showed that both could generate a robust immune system response. However, the IgG levels in the antiserum generated against the $\mathrm{C}$-terminal domain were relatively lower than full-length PFO. Both the proteins generated $\mathrm{T}$ cell memory and mixed immune response, which is a characteristic of a promising vaccine candidate as both the arms of immune response play an important role in conferring protection against the pathogen/toxin. The antisera generated against WTrPFO and the C-terminal domain could specifically recognize the full-length PFO and neutralize the hemolytic and cytotoxic activity of the PFO in vitro. The antiserum's specific and robust crossreactivity against the non-toxic $\mathrm{C}$-terminal domain with the full-length PFO and its ability to neutralize its toxicity clearly demonstrate that the C-terminal domain is nontoxic and has the potential to neutralize the toxicity of the PFO which is secreted by all clostridial toxino types. Since PFO has been reported to act in synergy with other main toxins of different clostridial strains, further in vivo immunization and protective efficacy studies of the PFO need to be carried out in combination with these toxins. Both WTrPFO and $\mathrm{rPFO}_{\mathrm{C} \text {-ter }}$ could also be used as an adjuvant vaccine together with other clostridial toxins as PFO has been reported to aid in the action of other clostridial toxins. Also, since the structure of PFO secreted by $C$. perfringens strains shares similarities with other cholesteroldependent cytolysins of other genera such as Streptococcus, Bacillus, and Listeria [8], the non-toxic variant of PFO reported in the present study could be assessed as a candidate for potentiating the protective immune responses against other bacterial infections as well.

Supplementary Information The online version contains supplementary material available at https://doi.org/10.1007/s12026-021-09254-9.

Acknowledgements AS thanks the Jawaharlal Nehru University, New Delhi, for the research fellowship. The authors acknowledge intramural support from the Jawaharlal Nehru University, New Delhi.

Author contribution Ankita Singh: Conceptualization, formal execution, analysis of all experiments, data curation, writing - original draft preparation.

Prashant Rawat: Initial investigations on recombinant protein expression

Aparna Dixit: Conceptualization, project administration, supervision, and writing - review and editing

Devapriya Choudhury: Writing, reviewing, and editing

\section{Declarations}

Conflict of interest The authors declare that they have no conflict of interest.

Ethics approval The Institutional Animal Ethics Committee of the university approved the use of animals for the immunization study (project code IAEC \# 03/2019). All procedures were performed as per the guidelines and recommendations of the committee.

\section{References}

1. Lebrun M, Mainil JG, Linden A. Cattle enterotoxaemia and Clostridium perfringens: description, diagnosis, and prophylaxis. Vet Rec. 2010;167:13-22. https://doi.org/10.1136/vr. 167.1.12.

2. Li M, Huang L, Zhu Y, Wei Q. Growth of Clostridium perfringens in roasted chicken and braised beef during cooling-one-step dynamic analysis and modeling. Food Control. 2019;106:106739. https://doi.org/10.1016/j.foodcont.2019.106739.

3. Miller WA, Miller MA, Gardner IA, Atwill ER, Byrne BA, Jang S, Harris M, Ames J, Jessup D, Paradies D, Worcester K. Salmonella spp., Vibrio spp., Clostridium perfringens, and Plesiomonas shigelloides in marine and freshwater invertebrates from coastal California ecosystems. Microb Ecol. 2006;52:198-206. https:// doi.org/10.1007/s00248-006-9080-6.

4. Hughes KA, Thompson A. Distribution of sewage pollution around a maritime Antarctic research station indicated by faecal coliforms, Clostridium perfringens, and faecal sterol markers. Environ Pollut. 2004;127:315-21. https://doi.org/10.1016/j. envpol.2003.09.004.

5. Uzal FA, Freedman JC, Shrestha A, Theoret JR, Garcia J, Awad MM, Adams V, Moore RJ, Rood JI, McClane BA. Towards an understanding of the role of Clostridium perfringens toxins in human and animal disease. Future Microbiol. 2014;9:361-77. https://doi.org/10.2217/fmb.13.168.

6. Revitt-Mills SA, Rood JI, Adams V. Clostridium perfringens extracellular toxins and enzymes: 20 and counting. Microbiol Aust. 2015;36:114-7. https://doi.org/10.1071/MA15039. 
7. Uzal FA, Vidal JE, McClane BA, Gurjar AA. Clostridium perfringens toxins involved in mammalian veterinary diseases. Open Toxicol J. 2010;2:24.

8. Petit L, Gibert M, Popoff MR. Clostridium perfringens: toxinotype and genotype. Trends Microbiol. 1999;7:104-10. https://doi. org/10.1016/S0966-842X(98)01430-9.

9. Songer JG. Clostridial enteric diseases of domestic animals. Clin Microbiol Rev. 1996;9:216-34. https://doi.org/10.1128/CMR.9. 2.216-234.1996.

10. Rood JI, Adams V, Lacey J, Lyras D, McClane BA, Melville SB, Moore RJ, Popoff MR, Sarker MR, Songer JG, Uzal FA, Van Immerseel F. Expansion of the Clostridium perfringens toxinbased typing scheme. Anaerobe. 2018;53:5-10. https://doi.org/ 10.1016/j.anaerobe.2018.04.011.

11. Kiu R, Hall LJ. An update on the human and animal enteric pathogen Clostridium perfringens. Emerg Microbes Infect. 2018;7:115. https://doi.org/10.1038/s41426-018-0144-8.

12. Awad MM, Ellemor DM, Boyd RL, Emmins JJ, Rood JI. Synergistic effects of alpha-toxin and perfringolysin $\mathrm{O}$ in Clostridium perfringens-mediated gas gangrene. Infect Immun. 2001;69:7904 10. https://doi.org/10.1128/IAI.69.12.7904-7910.2001.

13. Verherstraeten S, Goossens E, Valgaeren B, Pardon B, Timbermont L, Vermeulen K, Schauvliege S, Haesebrouck F, Ducatelle R, Deprez P, Van Immerseel F. The synergistic necrohemorrhagic action of Clostridium perfringens perfringolysin $\mathrm{O}$ and alpha toxin in the bovine intestine and against bovine endothelial cells. Vet Res. 2013;44:45. https://doi.org/10.1186/1297-9716-44-45.

14. Fernandez-Miyakawa ME, Jost BH, Billington SJ, Uzal FA. Lethal effects of Clostridium perfringens epsilon toxin are potentiated by alpha and perfringolysin-O toxins in a mouse model. Vet Microbiol. 2008;127:379-85. https://doi.org/10.1016/j.vetmic.2007.09. 013.

15. Verherstraeten S, Goossens E, Valgaeren B, Pardon B, Timbermont L, Haesebrouck F, Ducatelle R, Deprez P, Wade KR, Tweten R, Van Immerseel F. Perfringolysin O: The underrated Clostridium perfringens toxin? Toxins. 2015;7:1702-21. https://doi.org/ 10.1136/vr.167.1.12.

16. Muylaert A, Lebrun M, Duprez JN, Labrozzo S, Theys H, Taminiau B, Mainil J. Enterotoxaemia-like syndrome and Clostridium perfringens in veal calves. Vet Res. 2010;167:64-5. https://doi. org/10.1136/vr.b4869.

17. Chandran D, Naidu SS, Sugumar P, Rani GS, Vijayan SP, Mathur D, Garg LC, Srinivasan VA. Development of a recombinant epsilon toxoid vaccine against enterotoxemia and its use as a combination vaccine with live attenuated sheep pox virus against enterotoxemia and sheep pox. Clin Vaccine Immunol. 2010;17:1013-6 (http://hdl.handle.net/123456789/236).

18. Lobato FC, Lima CG, Assis RA, Pires PS, Silva RO, Salvarani FM, Carmo AO, Contigli C, Kalapothakis E. Potency against enterotoxemia of a recombinant Clostridium perfringens type D epsilon toxoid in ruminants. Vaccine. 2010;28:6125-7. https://doi. org/10.1016/j.vaccine.2010.07.046.

19. Goossens E, Verherstraeten S, Valgaeren BR, Pardon B, Timbermont L, Schauvliege S, Rodrigo-Mocholí D, Haesebrouck F, Ducatelle R, Deprez PR, Van Immerseel F. Toxin- neutralizing antibodies protect against Clostridium perfringens-induced necrosis in an intestinal loop model for bovine necrohemorrhagic enteritis. BMC Vet Res. 2016;12:101-101. https://doi.org/10. 1186/s12917-016-0730-8.

20. Goossens E, Verherstraeten S, Valgaeren BR, PardonB Timbermont L, Schauvliege S, Rodrigo-Mocholí D, Haesebrouck F, Ducatelle R, Deprez PR, Van Immerseel F. The C-terminal domain of Clostridium perfringens alpha toxin as a vaccine candidate against bovine necrohemorrhagic enteritis. Vet Res. 2016;47:1-9. https:// doi.org/10.1186/s13567-016-0336-y.
21 Milach A, de los Santos JRG, Turnes CG, Moreira ÂN, de Assis RA, Salvarani FM, Lobato FCF, Conceição FR. Production and characterization of Clostridium perfringens recombinant $\beta$ toxoid. Anaerobe. 2012;18:363-5. https://doi.org/10.1016/j.anaerobe. 2012.01.004.

22. Salvarani FM, Conceicão FR, Cunha CE, Moreira GM, Pires PS, Silva RO, Alves GG, Lobato FC. Vaccination with recombinant Clostridium perfringens toxoids $\alpha$ and $\beta$ promotes elevated antepartum and passive humoral immunity in swine. Vaccine. 2013;31:4152-5. https://doi.org/10.1016/j.vaccine.2013.06.094.

23 Langroudi RP, Shamsara M, Aghaiypour K. Expression of Clostridium perfringens epsilon-beta fusion toxin gene in $E$. coli and its immunologic studies in mouse. Vaccine. 2013;31:3295-9. https://doi.org/10.1016/j.vaccine.2013.04.061.

24. Moreira GMSG, Salvarani FM, Da Cunha CEP, Mendonça M, Moreira ÂN, Gonçalves LA, Pires PS, Lobato FCF, Conceição FR. Immunogenicity of a trivalent recombinant vaccine against Clostridium perfringens alpha, beta, and epsilon toxins in farm ruminants. Sci Rep. 2016;6:1-9. https://doi.org/10.1038/srep2 2816.

25. Rossjohn J, Feil SC, McKinstry WJ, Tweten RK, Parker MW. Structure of a cholesterol-binding, thiol-activated cytolysin and a model of its membrane form. Cell. 1997;89:685-92. https://doi. org/10.1016/S0092-8674(00)80251-2.

26. Heuck AP, Savva CG, Holzenburg A, Johnson Johnson AE. Conformational changes that affect oligomerization and initiate pore formation are triggered throughout perfringolysin $\mathrm{O}$ upon binding to cholesterol. J Biol Chem. 2007;282:22629-37. https://doi.org/ 10.1074/jbc.M703207200.

27. Farrand AJ, LaChapelle S, Hotze EM, Johnson AE, Tweten RK. Only two amino acids are essential for cytolytic toxin recognition of cholesterol at the membrane surface. Proc Natl Acad Sci U S A. 2010;107:4341-6. https://doi.org/10.1073/pnas.0911581107.

28. Shimada Y, Maruya M, Iwashita S, Ohno-Iwashita Y. The C-terminal domain of perfringolysin $\mathrm{O}$ is an essential cholesterol-binding unit targeting to cholesterol-rich microdomains. Eur J Biochem. 2002;269:6195-203. https://doi.org/10.1046/j.1432-1033. 2002.03338.x.

29. Yadav SK, Meena JK, Sharma M, Dixit A. Recombinant outer membrane protein $\mathrm{C}$ of Aeromonas hydrophila elicits mixed immune response and generates agglutinating antibodies. Immunol Res. 2016;64:1087-99. https://doi.org/10.1007/ s12026-016-8807-9.

30. Karan S, Mohapatra A, Sahoo PK, Garg LC, Dixit A. Structuralfunctional characterization of recombinant apolipoprotein A-I from Labeo rohita demonstrates heat-resistant antimicrobial activity. Appl Microbiol Biotechnol. 2020;104:145-59. https://doi.org/ 10.1007/s00253-019-10204-7.

31. Sharma M, Dash P, Sahoo PK, Dixit A. Th2-biased immune response and agglutinating antibodies generation by a chimeric protein comprising OmpC epitope (323-336) of Aeromonas hydrophila and LTB. Immunol Res. 2018;66:187-99. https://doi. org/10.1007/s12026-017-8953-8.

32. Sharma M, Dixit A. Identification and immunogenic potential of B cell epitopes of outer membrane protein OmpF of Aeromonas hydrophila in translational fusion with a carrier protein. Appl Microbiol Biotechnol. 2015;99:6277-91. https://doi.org/10.1007/ s00253-015-6398-3.

33. Frey A, Di Canzio J, Zurakowski D. A statistically defined endpoint titer determination method for immunoassays. J Immunol Methods. 1998;221:35-41. https://doi.org/10.1016/S00221759(98)00170-7.

34. Tweten RK. Cloning and expression in Escherichia coli of the perfringolysin $\mathrm{O}$ (theta-toxin) gene from Clostridium perfringens and characterization of the gene product. Infect Immun. 1988;56:3228-34. 
35. Hanson MS, Stephenson AH, Bowles EA, Sridharan M, Adderley S, Sprague RS. Phosphodiesterase 3 is present in rabbit and human erythrocytes and its inhibition potentiates iloprostinduced increases in cAMP. Am J Physiol Heart Circ Physiol. 2008;295:H786-93. https://doi.org/10.1152/ajpheart.00349.2008.

36. Ray A, Dittel BN. Isolation of mouse peritoneal cavity cells. J Vis Exp. 2010;35:1488. https://doi.org/10.3791/1488.

37. Verherstraeten S, Goossens E, Valgaeren B, Pardon B, Timbermont L, Haesebrouck F, Ducatelle R, Deprez P, Van Immerseel F. Non-toxic perfringolysin $\mathrm{O}$ and $\alpha$-toxin derivatives as potential vaccine candidates against bovine necrohaemorrhagic enteritis. Vet J. 2016;217:89-94. https://doi.org/10.1016/j.tvj1.2016.09.008.

38. Williamson ED, Titball RW. A genetically engineered vaccine against the alpha-toxin of Clostridium perfringens protects mice against experimental gas gangrene. Vaccine. 1993;11:1253-8. https://doi.org/10.1016/0264-410X(93)90051-X.

39. Stevens DL, Titball RW, Jepson M, Bayer CR, Hayes-Schroer $\mathrm{SM}$, Bryant AE. Immunization with the C-domain of $\alpha$-toxin prevents lethal infection, localizes tissue injury, and promotes host response to challenge with Clostridium perfringens. J Infect Dis. 2004;190:767-73. https://doi.org/10.1086/422691.

40. Jiang Z, De Y, Chang J, Wang F, Yu L. Induction of potential protective immunity against enterotoxemia in calves by single or multiple recombinant Clostridium perfringens toxoids. Microbiol Immunol. 2014;58:621-7. https://doi.org/10.1111/1348-0421. 12198.

41. Dunstone MA, Tweten RK. Packing a punch: the mechanism of pore formation by cholesterol dependent cytolysins and membrane attack complex/perforin-like proteins. Curr Opin Struct Biol. 2012;22:342-9. https://doi.org/10.1016/j.sbi.2012.04.008.
42. Weis S, Palmer M. Streptolysin O: the C-terminal, tryptophanrich domain carries functional sites for both membrane binding and self-interaction but not for stable oligomerization. Biochim Biophys Acta. 2001;1510:292-9. https://doi.org/10.1016/S00052736(00)00360-6.

43. Cheers C, Janas M, Ramsay A, Ramshaw I. Use of recombinant viruses to deliver cytokines influencing the course of experimental bacterial infection. Immunol Cell Biol. 1999;77:324-30. https:// doi.org/10.1046/j.1440-1711.1999.00829.x.

44. Yadav SK, Sahoo PK, Dixit A. Characterization of immune response elicited by the recombinant outer membrane protein OmpF of Aeromonas hydrophila, a potential vaccine candidate in murine model. Mol Biol Rep. 2014;41:1837-48. https://doi.org/ 10.1007/s11033-014-3033-9.

45. O'Brien DK, Melville SB. Effects of Clostridium perfringens alpha-toxin (PLC) and perfringolysin O (PFO) on cytotoxicity to macrophages, on escape from the phagosomes of macrophages, and on persistence of $C$. perfringens in host tissues. Infect Immun. 2004;72:5204-15. https://doi.org/10.1128/IAI.72.9.5204-5215. 2004.

46. Virella G, Tsokos GC. The pathogenic role of antigen-antibody complexes. In Medical Immunology. 7th ed. Milton: CRC Press LLC; 2019.

Publisher's note Springer Nature remains neutral with regard to jurisdictional claims in published maps and institutional affiliations. 